\title{
Incidence and Ramifications of Armed Conflict in Countries with Major Desert Locust Breeding Areas
}

\author{
Allan T. Showler ${ }^{1, *}$ and Michel Lecoq ${ }^{2}$ (D) \\ 1 Knipling-Bushland U.S. Livestock Insects Research Laboratory, USDA-ARS, 2700 Fredericksburg Road, \\ Kerrville, TX 78028, USA \\ 2 CIRAD, UMR CBGP, F-34398 Montpellier, France; mlecoq34@gmail.com \\ * Correspondence: allan.showler@ars.usda.gov; Tel.: +1-(830)-792-0341
}

Citation: Showler, A.T.; Lecoq, M. Incidence and Ramifications of Armed Conflict in Countries with Major Desert Locust Breeding Areas. Agronomy 2021, 11, 114. https:// doi.org/10.3390/agronomy11010114

Received: 1 December 2020

Accepted: 5 January 2021

Published: 8 January 2021

Publisher's Note: MDPI stays neutral with regard to jurisdictional clai$\mathrm{ms}$ in published maps and institutional affiliations.

Copyright: $\odot 2021$ by the authors. Licensee MDPI, Basel, Switzerland. This article is an open access article distributed under the terms and conditions of the Creative Commons Attribution (CC BY) license (https:// creativecommons.org/licenses/by/ $4.0 /)$.

\begin{abstract}
Despite many areas of progress in recent years, desert locust surveillance and control is impaired by many obstacles, the most intractable of which is insecurity. Insecurity involves rebellions, insurgencies, civil and international war, banditry, terrorism, and minefields. Obstruction of desert locust operations in breeding areas by ongoing armed conflict and landmines constitutes "direct" insecurity. "Indirect" insecurity, although less obvious, is arguably more broadly deleterious by debilitating government function and diverting funds, personnel, and equipment from desert locust management. Indirect "active" insecurity is armed conflict and civil unrest that is occurring at the same time as a desert locust episode, but not in the breeding areas. Indirect "inactive" insecurity refers to the after-effects of insecurity, including weak funding because of prior inattention to capacity maintenance during times of direct and indirect active insecurity, disabled or militarily-appropriated vehicles and other resources, destruction of infrastructure, and deployment of mines. We provide examples of direct and indirect insecurity across 35 years, from 1986 through May 2020, in 13 African and Asian countries (Chad, Eritrea, Ethiopia, India, Mali, Mauritania, Niger, Pakistan, Saudi Arabia, Somalia, Sudan, Western Sahara, and Yemen) with desert locust breeding areas to illustrate the complexity, pervasiveness, and chronic occurrence of insecurity. The upsurge of 2020 is used to show how direct insecurity still contributes to the genesis and expansion of desert locust episodes. Possible mitigation of direct insecurity effects on some desert locust operations is discussed.
\end{abstract}

Keywords: control; impediments; insecurity; plague; Schistocerca gregaria; surveillance; war

\section{Introduction}

The desert locust, Schistocerca gregaria (Forskål) (Orthoptera: Acrididae), is arguably the oldest and most agriculturally threatening migratory pest globally [1]. Since 1989, following a desert locust plague, control has evolved toward proactive intervention [2,3] during outbreaks to avert the development of upsurges and plagues with notable success $[4,5]$. Further, control is evolving past proactive control toward outbreak prevention with the aim of holding desert locust populations in their nongregarious recession stage for indefinite periods of time [4,5]. Despite notable successes and advances in the science of desert locust management and available technologies [4,5], major constraints remain, including insufficient funding, political issues, unpreparedness, impediments to research, and rugged and remote terrain with weak infrastructure [4]. Another key constraint, insecurity, involves rebellions, banditry, civil and international war, terrorism, and minefields (Figure 1) [4-8]. Large areas in the desert locust distribution [7,9] cannot be surveyed for desert locust activity due to chronic insecurity, which constitutes a serious risk for proactive and preventative strategies $[4,5,10]$. Insecurity has been a major challenge to surveillance and control by blocking access $[4,8]$ to desert locust breeding areas in Africa and Asia [9] (Figure 2). Desert locust control is unique in that it is conducted across vast expanses and it requires coordination within and between afflicted countries. Surveillance should chiefly focus on the main breeding, or "outbreak areas" [11,12]. Major desert 
locust breeding areas are mainly located around massifs across the Sahara Desert and Mauritania, the Red Sea plains on the east and west coasts, parts of the southern Arabian Peninsula, and the India-Pakistan border [4,7,9], all of which are frequently beset with insecurity [8]. Occurrences and effects of insecurity are described herein from 1986 through May $2020[4,6]$. Desert locusts can invade and reproduce in countries beyond those harboring key breeding areas $[4-7,9]$, but we selected examples that have major breeding areas for illustrative purposes.

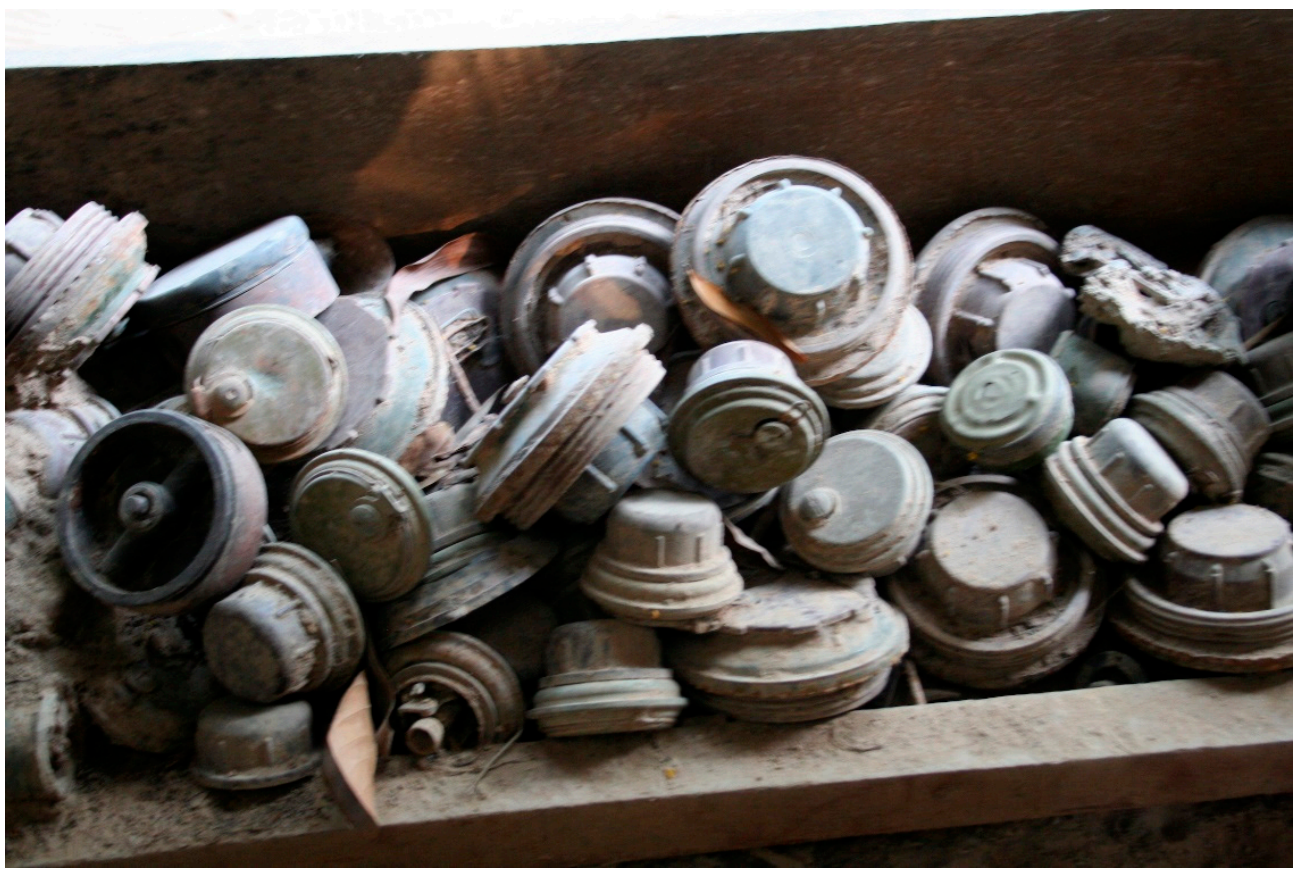

Figure 1. Landmines limit access to some areas frequented by desert locusts; photo credit Neil Rickards.

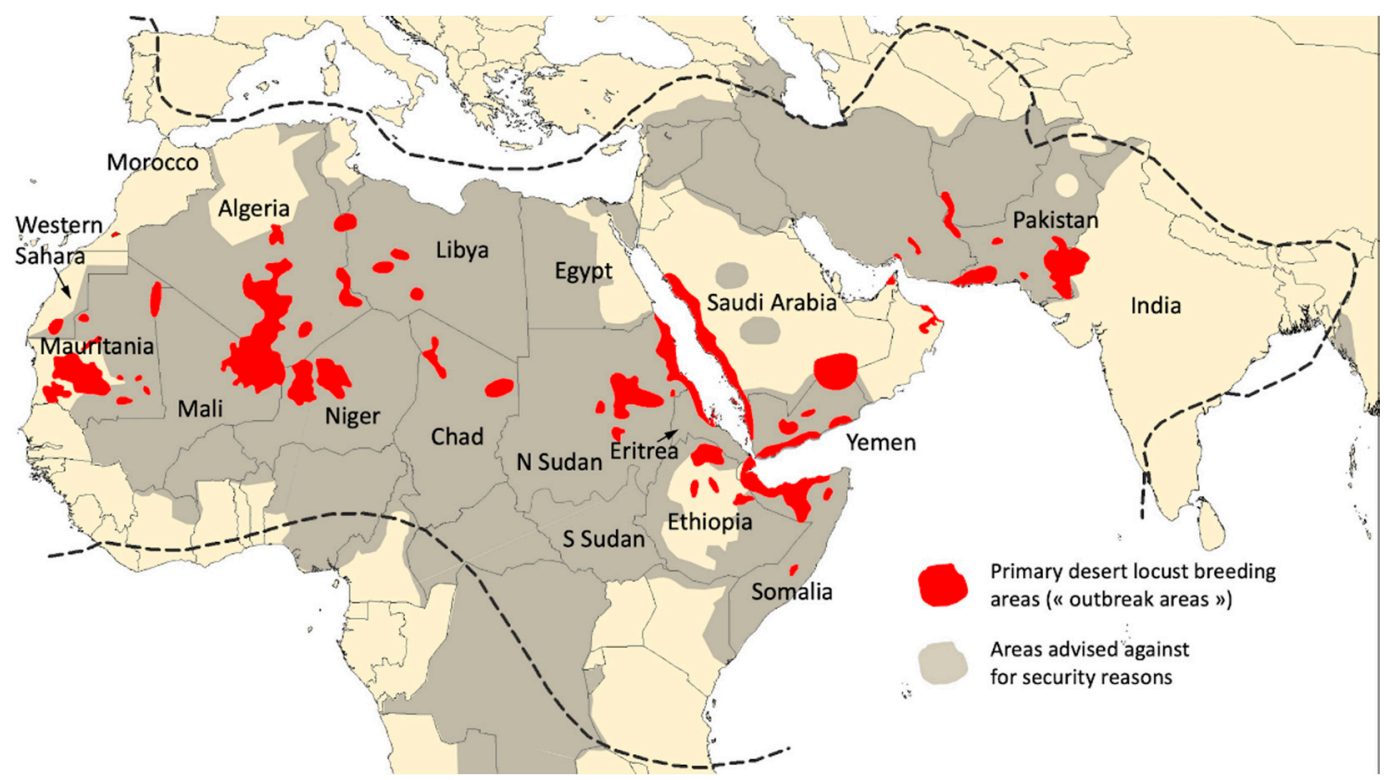

Figure 2. Proximity and overlap of major desert locust breeding areas with areas advised against and formally advised against by the French Ministry of Europe and Foreign Affairs for safety concerns [13] and other foreign ministries and departments of other "western" countries; the dotted lines indicate the limits of the desert locust invasion area [12]; 1986 through October 2020. 
Insecurity can impede desert locust operations directly and indirectly. Direct insecurity obstructs ground and aerial surveillance and control operations in breeding areas by imperiling personnel and equipment. Further, swarms originating in non-contested areas can fly into conflicted zones where they might not be accessible for control. Unlike most other kinds of insect control campaigns, desert locust operations are, with relative frequency in some countries, impeded by direct insecurity.

Indirect insecurity, although less obvious than direct insecurity, is arguably more broadly deleterious by debilitating government function and diverting focus away from agricultural issues, and by diverting funding, personnel, and equipment (e.g., vehicles) from desert locust management. Indirect insecurity can be "active" and "inactive". Indirect active insecurity is armed conflict and civil unrest that is occurring at the same time as the desert locust episode, but not in the breeding areas. Because of the apparent constancy and diversity of conflicts in many countries with desert locust breeding areas, indirect active insecurity is widespread, persistent, and dynamic. Indirect inactive insecurity refers to the after-effects of insecurity regardless of where it had occurred. Impacts include weak funding due to prior inattention to capacity maintenance during times of direct and indirect active insecurity, disabled or government-appropriated vehicles and other resources, destruction of infrastructure, and deployment of mines. Indirect inactive insecurity is, because of the frequency of indirect active insecurity, also persistent. Dormant hostilities, such as those between Israel and some of its neighboring countries, are examples of indirect inactive insecurity. Further, desert locust upsurges and plagues are linked to loss of feed production; displacements of human populations; conflicts between farmers, nomads, and pastoralists over limited resources [14], all of which are exacerbated and compounded by the chronic, sweeping, and pernicious effects of indirect (active and inactive) insecurity. While we cannot measure the influence of indirect insecurity on desert locust management, we can report the incidence of insecurity to provide a sense of scope and magnitude, as well as variability between afflicted countries.

Because early intervention and reactive control require concentrated use of resources during time-limited windows of opportunity, depletion of resources contributes toward non-sustainability, which underlies the primary obstacle to early intervention (proactive and preventive): Unpreparedness [4,6,10,15-17]. Insecurity is often accompanied by increased reliance on bilateral and multilateral international aid agencies for development, routine operations, and non-conflict-related disasters and emergencies, such as combatting desert locust upsurges and plagues. Ramifications of indirect insecurity erode national desert locust control capabilities particularly during recession periods $[16,17]$. In addition, chronic demand for external support to suppress a recurrent emergency has resulted in "donor fatigue", a condition associated with dwindling funds, especially during recessions when there is no immediate emergency to mobilize and drive continued international aid agency support.

\section{Insecurity in Countries with Major Desert Locust Breeding Areas}

Algeria. Direct Insecurity. "Traditional" desert locust breeding areas are located in southern Algeria, particularly around the Ahaggar Mountains, and many swarms invaded north of the Atlas Mountains during the 1986-1989 plague and the 2003-2005 upsurge (Figure 3) [6,14]. Some areas in the 1980s and 1990s were insecure due to limited Tuareg unrest in the south and travel was restricted near Western Sahara. From 2007 through 2016, however, outbreaks were effectively controlled $[4,18]$. 


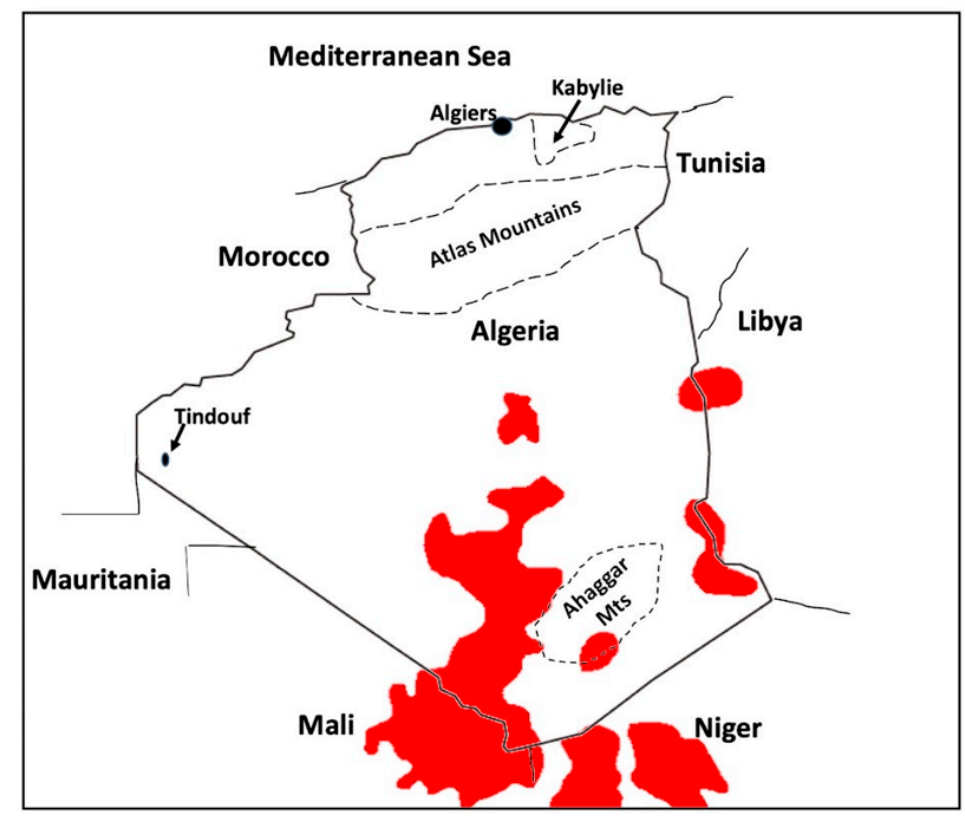

Figure 3. Locations and regions mentioned in the text in relation to desert locust activity and insecurity in Algeria. Primary breeding areas in red.

Indirect Insecurity. Islamic extremism began after a general election was curtailed by the government in 1992 when Islamic fundamentalists were expected to win [19]. During the next 10 years, $\approx 150,000$ people were killed and the government sank into political paralysis [20,21]. Attendant civil unrest included assassinations, massacres, and rioting, hindering travel to and within Algeria [8]. In 2001, a Berber uprising occurred in the Kabylie region (Figure 3) [22,23], and in 2007 an al-Qaeda faction carried out assassinations, kidnappings, and bombings; the army responded with anti-insurgency offensives [22-25]. Although a 19-year-long national emergency was lifted in 2011, public protests and terrorist attacks by al-Qaeda and other insurgent groups continued through 2016 [23]. The north was most insecure [22], but al-Qaeda's southern branch accrued strength [26]; Libya's civil war produced a weapons influx which helped arm al-Qaeda in Algeria [22,27], increasing ambushes and use of concealed explosives against security forces [28]. Indirect active and inactive insecurity obstructed governance, limited funding, and restricted movement, hindering anti-locust capabilities [8].

Chad. Direct Insecurity. Desert locust breeding largely occurs in the northwestern mountainous Tibesti and Ennedi regions (Figure 4) [29,30]. In 1973, Libya attempted to annex Chad's Aouzou strip, part of the desert locust's Tibesti (Figure 4) breeding area [29], but Chad retook it militarily in 1986 and travel there was prohibited until the early 1990s [31-34]. During the 1986-1989 campaign, control operations were often halted because of conflict with Libya [8]. Civil war, mostly in the Tibesti region between the government, and the Movement for Democracy and Justice and the National Resistance Army [35], obstructed travel to the region and impaired desert locust operations through $2016[4,18]$. 


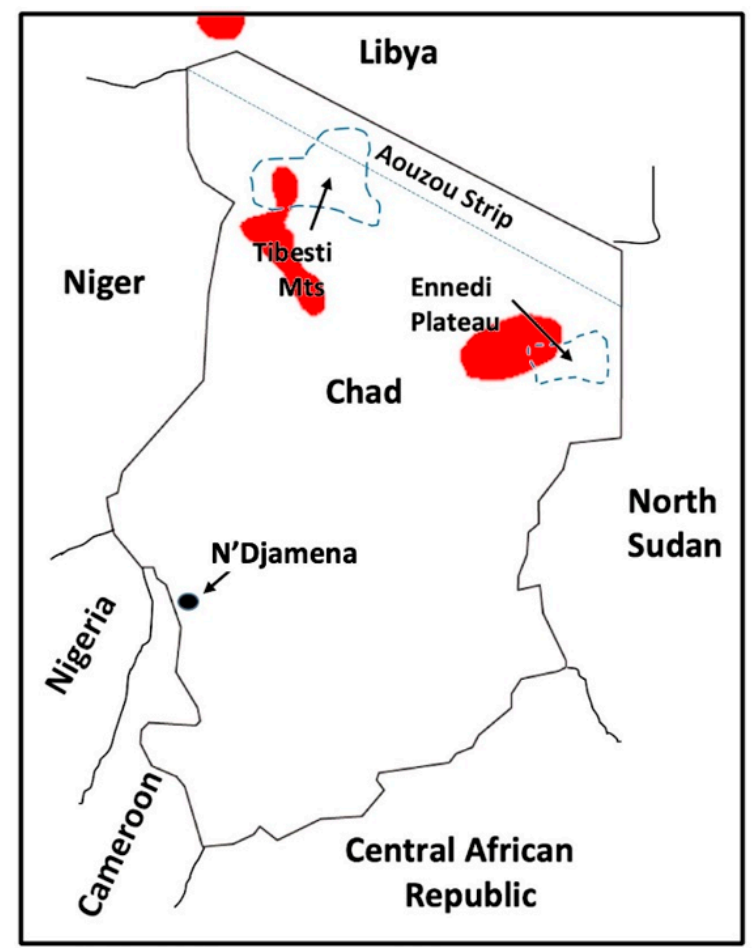

Figure 4. Locations and regions mentioned in the text in relation to desert locust activity and insecurity in Chad. Primary breeding areas in red.

Indirect Insecurity. The Mouvement Patriotique du Salut and other rebel groups replaced Chad's government in 1990 [27,36], and insurgency-based coup attempts became chronic $[36,37]$. During the 1990s, the border with the Central African Republic (Figure 4) was contested [38] between a group called the Federal Republic of Laouken and Chadian troops [8].

Border tension in eastern Chad deteriorated in 2005 when Chadian rebel groups used the region for bases (supported by Sudan), Sudanese militia groups also entered Chad and attacked civilians, instigating violence between eastern ethnic groups [36]. In April 2006, three rebel groupls, Union des Forces pour la Démocratie et le Dévelopment, Rassemblement des Forces pour le Changement, and the Front Uni pour le Changement, started an unresolved offensive against the national army with casualties on both sides [36], prompting the government to declare a national emergency in 2007 [37]. In early 2008, the same rebel groups entered N'Djamena (Figure 4), but failed to topple the government [36]. A rebel advance in May 2009 elicited government airstrikes against their sanctuaries across the border in Sudan [37]. Sudan countered by launching an airstrike on a Chadian refugee camp and by pursuing Sudanese rebels that had taken refuge in Chad; Chad retaliated with July airstrikes against Sudan [37]. In 2010, Chad and Sudan deployed a 3000-soldier combined cross-border force to quell problematic opposition groups [37]. Other rebel organizations have since emerged and conflict continues. We suggest that indirect insecurity, active and inactive, have had a substantial deleterious impact on Chadian governmental functions, including locust surveillance and control.

Eritrea. Direct Insecurity. The Red Sea coastal plain of Eritrea, particularly north of Massawa (Figure 5), has, along with the contiguous coastal plains of Sudan, likely been the most prolific breeding area for desert locusts. The 1986-1989 plague and the 1992-1994 upsurge both originated on the Red Sea coastal plains in Eritrea and Sudan [6,7]. A war for independence waged by the Eritrean People's Liberation Front (EPLF) against Ethiopia began in 1962 and continued for 30 years [39] (Figures 6 and 7), escalating to large tank battles. Fighting occurred everywhere, excluding the capital, Asmara (Figure 5) [39]. The war prevented desert locust control during the 1986-1989 plague [4,6,15], and during the 
1992-1994 upsurge, minefields obstructed access to breeding areas [7]. Following independence in 1993, minefields still made off-road travel in the lowlands so dangerous [40] that some operations had to be conducted using aircraft [8]. The Sudan border was intermittently conflicted after Eritrea's independence [8] because of Eritrean support for Sudanese rebels [41] and a suspected Sudanese-backed insurgency within Eritrea [8,42]. In 1999, an Eritrean desert locust surveillance team was captured near the border, detained, and tortured [8]. Despite continued hostilities, 1997-2020 desert locust control was reasonably successful [4].

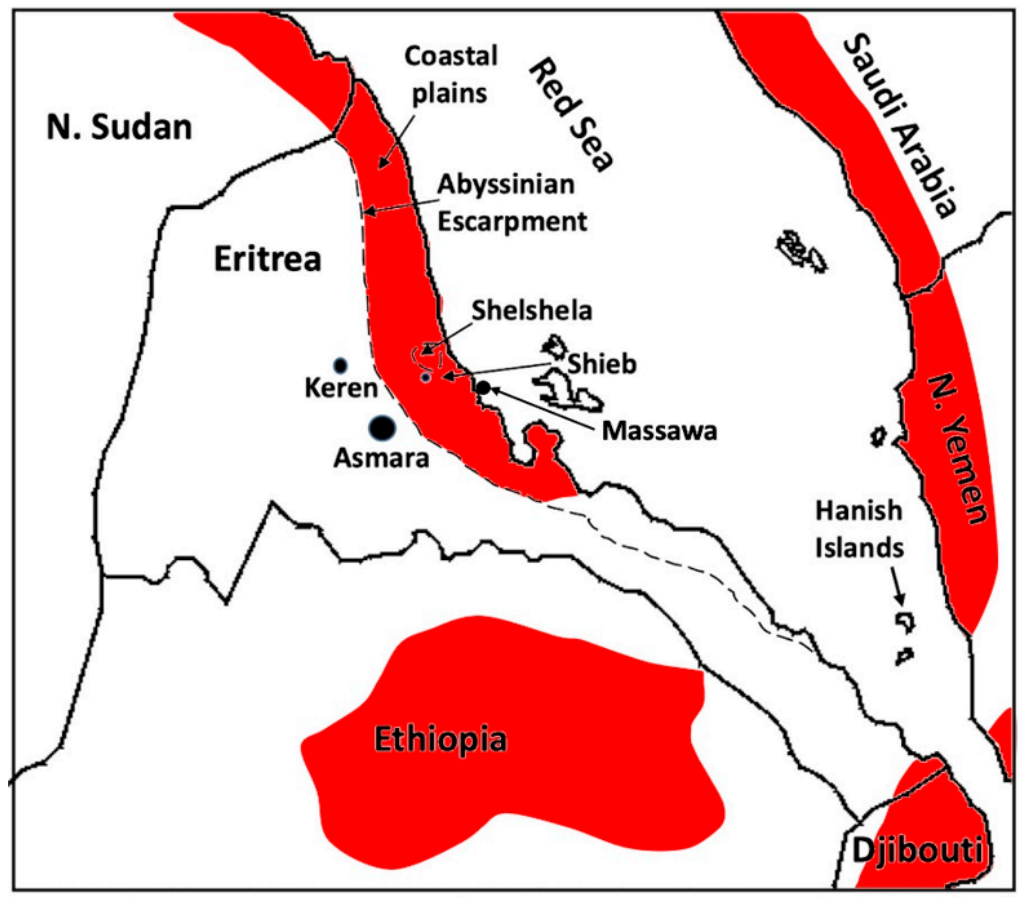

Figure 5. Locations and regions mentioned in the text in relation to desert locust activity and insecurity in Eritrea. Primary breeding areas in red.

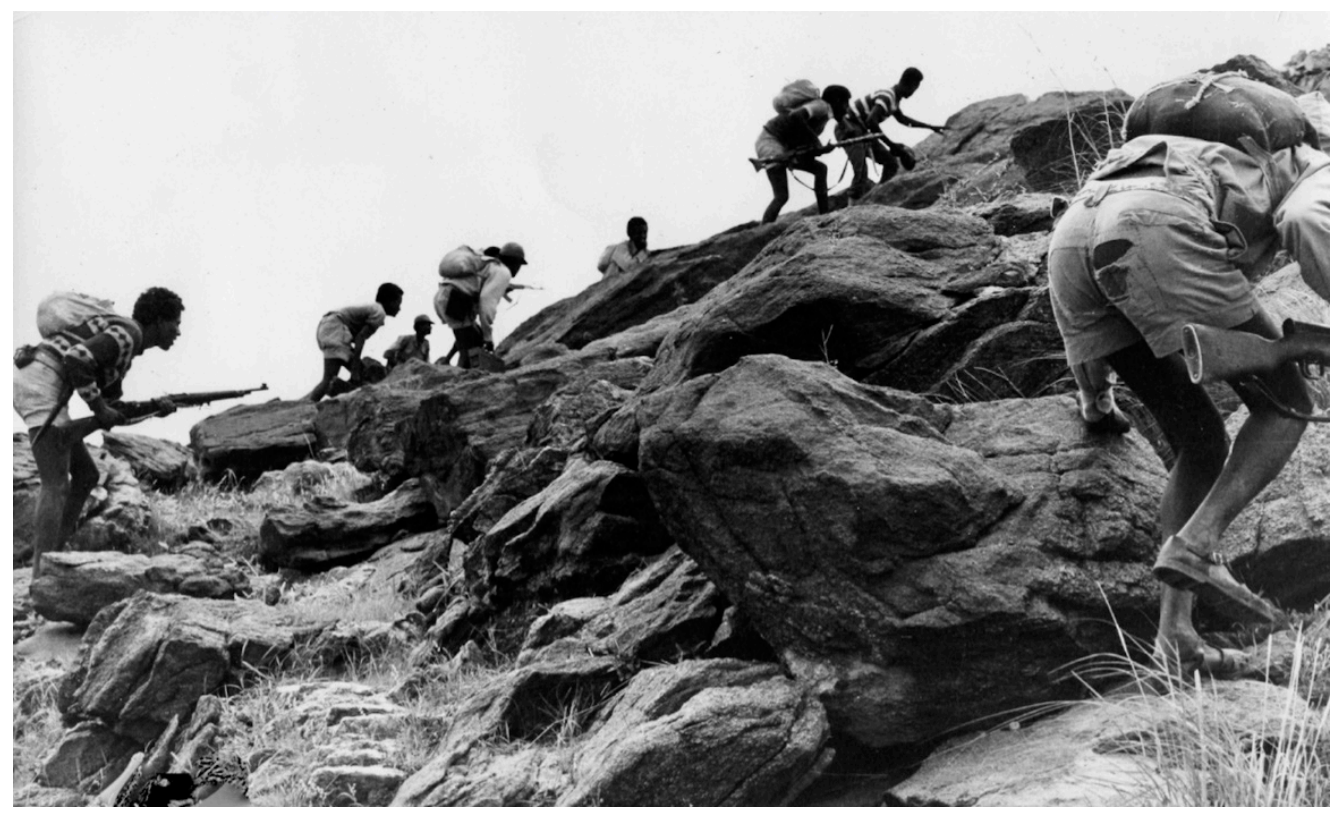

Figure 6. Eritrean People's Liberation Front (EPLF) soldiers during the war for independence from Ethiopia; photo credit Gwynne Roberts (copyright Gwynne Roberts). 


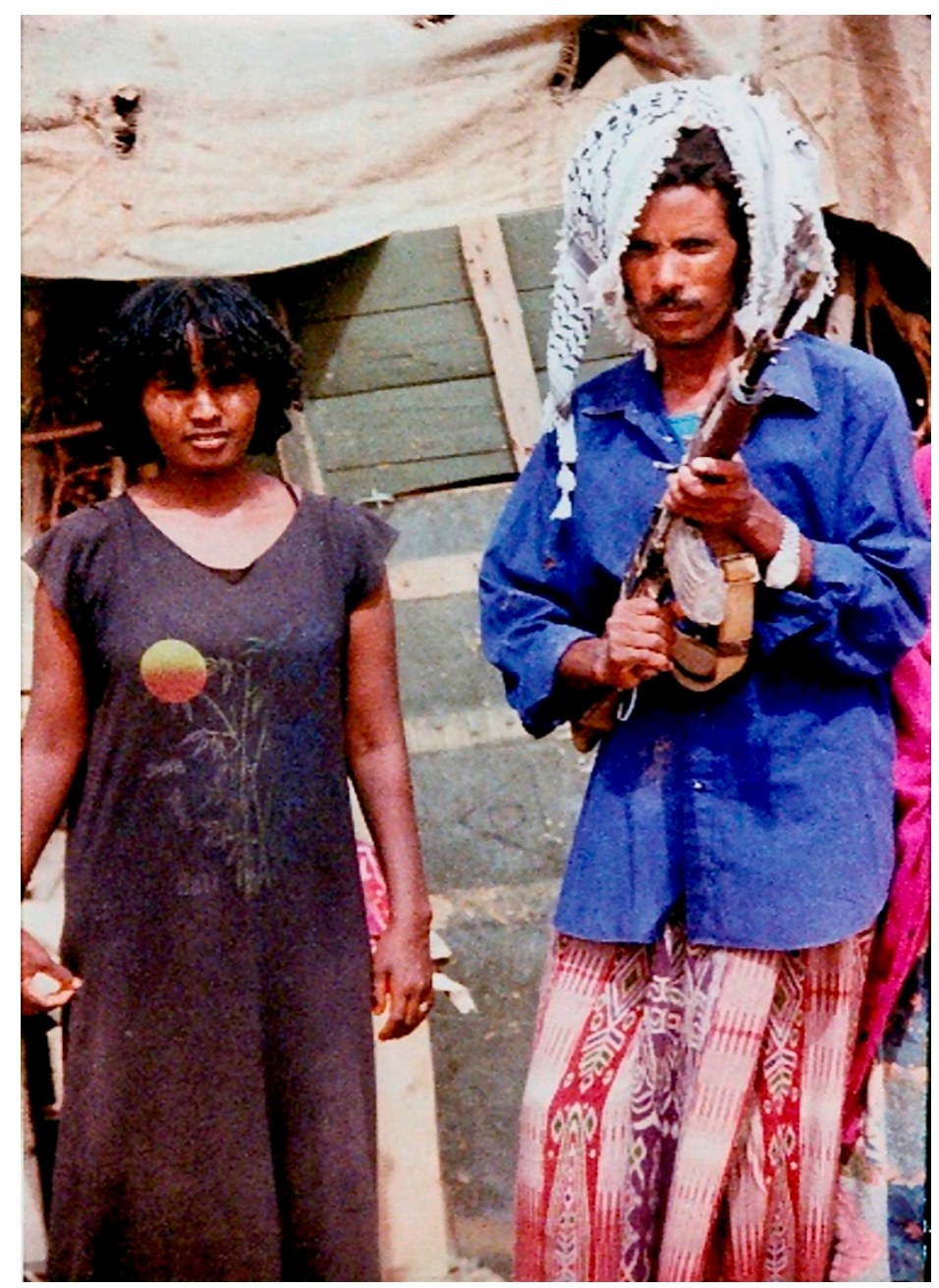

Figure 7. EPLF fighter, holding AK-47, who served 15 years on the front lines, with his wife who served on the front lines for 10 years; Eritrean women train and fight alongside men and they were reputed to be ferocious in battle; photo credit Allan Showler.

Indirect Insecurity. In addition to the direct danger of landmines, the 1992-1994 upsurge started on the coastal plain [7] because of unpreparedness following the long war for independence [7,8]. In 1996, Eritrean forces displaced Yemeni troops on the Red Sea Hanish Islands (Figure 5), disrupting communication and travel between the two countries until resolution in 1998 [8,43]. Additionally in 1996, Islamic (possibly Sudanese) insurgents killed Eritreans and Belgians along the Abyssinian escarpment "Filfil" road connecting Keren to the coastal plain near Shelshela, a prolific desert locust breeding area (Figure 5) [8].

Ethiopia launched airstrikes against Asmara in 1998 over a border dispute and Eritrea responded with an airstrike against Mekele in northern Ethiopia (Figure 5) [8]. War ensued, involving tens of thousands of casualties until Ethiopia invaded part of southwestern Eritrea in June 2000. A United Nations peacekeeping force arrived in 2002 but disbanded in 2008 despite continuing tension [44] and the border remained inaccessible and tense through 2020, even after the two countries reached a peace agreement in 2018. Continuous military mobilization since independence has prevented Eritrea from reaching optimal capacity for desert locust control.

Ethiopia. Direct Insecurity. From 1986, parts of the Ogaden Desert (Figure 8), where desert locusts breed, were unsafe because of rebellions and banditry; in 1992, for example, a surveillance helicopter was shot down there, killing three [8]. The senior author, on lowflying reconnaissance near Jijiga (Figure 8), 1994, was targeted by small arms. Although 
control operations have more recently been effective, dangers in some areas, particularly the Ogaden, remain.

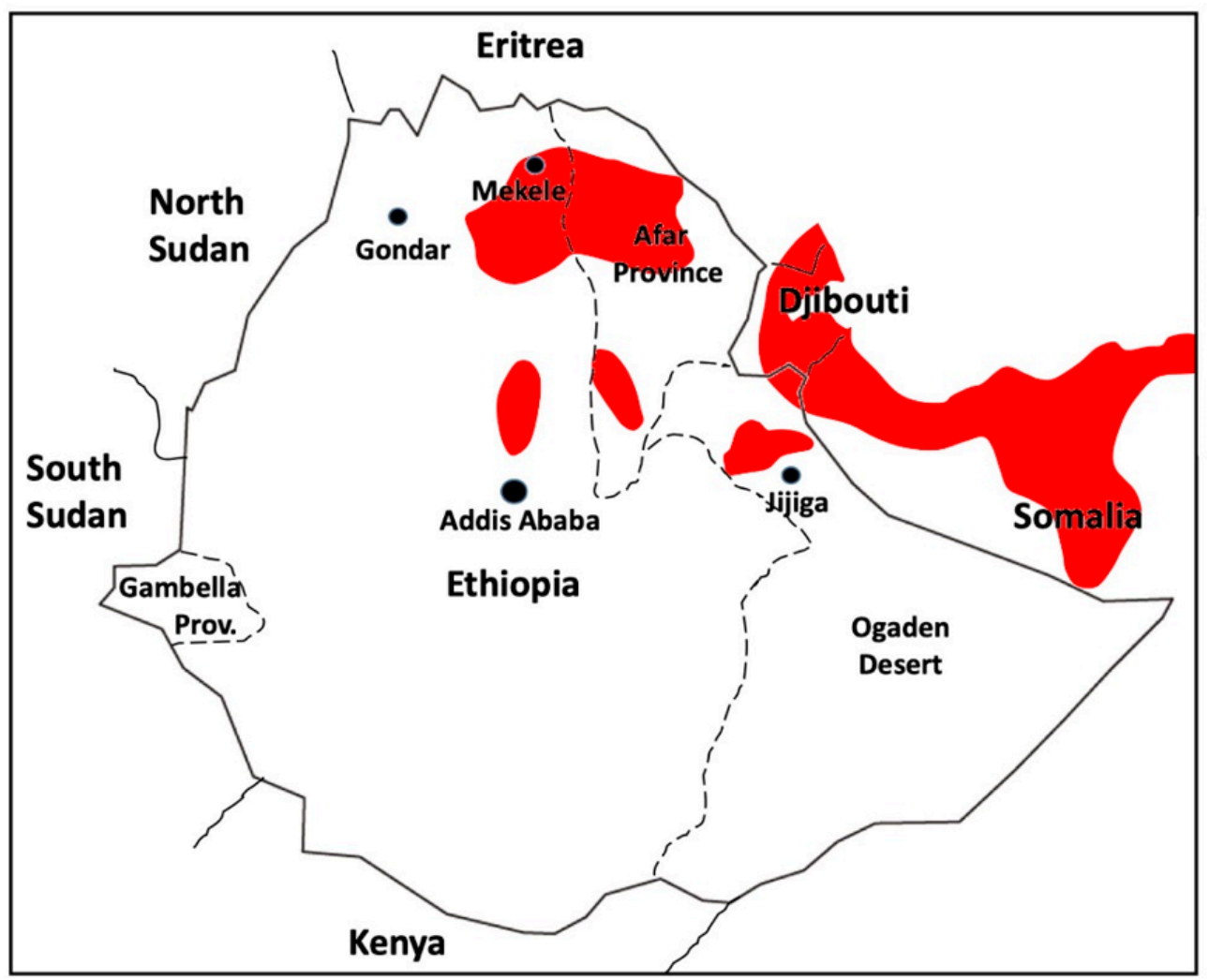

Figure 8. Locations and regions mentioned in the text in relation to desert locust activity and insecurity in Ethiopia. Primary breeding areas in red.

Indirect Insecurity. Aside from the 1962-1992 war of Eritrean secession, rebellions and civil unrest besieged Ethiopia from 1986 through 2020. A civil war during the 1980s involved the Ethiopian People's Revolutionary Democratic Front, which replaced the dictatorial Derg regime in 1991 [45]. The Sudan border was intermittently tense, and in 2000 Kenya reported that Ethiopian soldiers repeatedly crossed the border (Figure 8), killing Kenyan citizens and stealing cattle [8].

In 2004, $\approx 200$ people died in ethnic clashes in Gambella Province (Figure 8), causing massive population displacement [46]. In 2005, disputed elections led to violent protests lasting months, in 2006 several bombs exploded in Addis Ababa, and Ethiopian troops were sent into Somalia for two years to combat Islamist militants [46]. In 2007, insurgents killed 74 workers at a Chinese oil facility in the southeast [46]. The Ogaden National Liberation Front (ONLF) captured several eastern towns in 2009 after heavy fighting [46], and clashes with the military continued into 2012, one raid killing 168 troops [46]. Further, European tourists were executed in the Afar region (Figure 8). In 2013, Ethiopia detained Somali al-Shabaab Islamist militants plotting to kidnap United Nations personnel [47], and, in 2015-2016, protests erupted in the northern city of Gondar (Figure 8) associated with the killing of $>500$ people and other human rights abuses by the government, prompting a state of emergency in late 2016 [46]. Occasionally, violent civil unrest in Ethiopia persisted through 2020. Although effects of indirect insecurity on Ethiopia's ability to manage desert locusts are highly likely, it is difficult to assess the extent of impairment.

India-Pakistan. Indirect Insecurity. The Thar Desert (Figure 9) on the southern border of India and Pakistan comprise the easternmost key desert locust breeding area [9,29]. Direct insecurity in the breeding areas, 1986-2020, has not been reported. During the desert locust campaigns of 1986-1989 and 1992-1994, involving breeding in the border 
deserts, control occurred before swarms escaped to other regions [6,7], but cooperation between India and Pakistan was problematic because of limited communications, travel restrictions to contested areas, and landmines [48]. Mutual hostility between the two countries escalated into a nuclear arms race [49,50]. From 1986 through 2020, conflict has mostly been focused on the Kashmir region (Figure 9). Terrorism and military skirmishes, including airstrikes, were conducted there, resulting in thousands of casualties [51-56]. India and Pakistan are likely among the countries (of the 13 presented) least impeded by indirect insecurity.

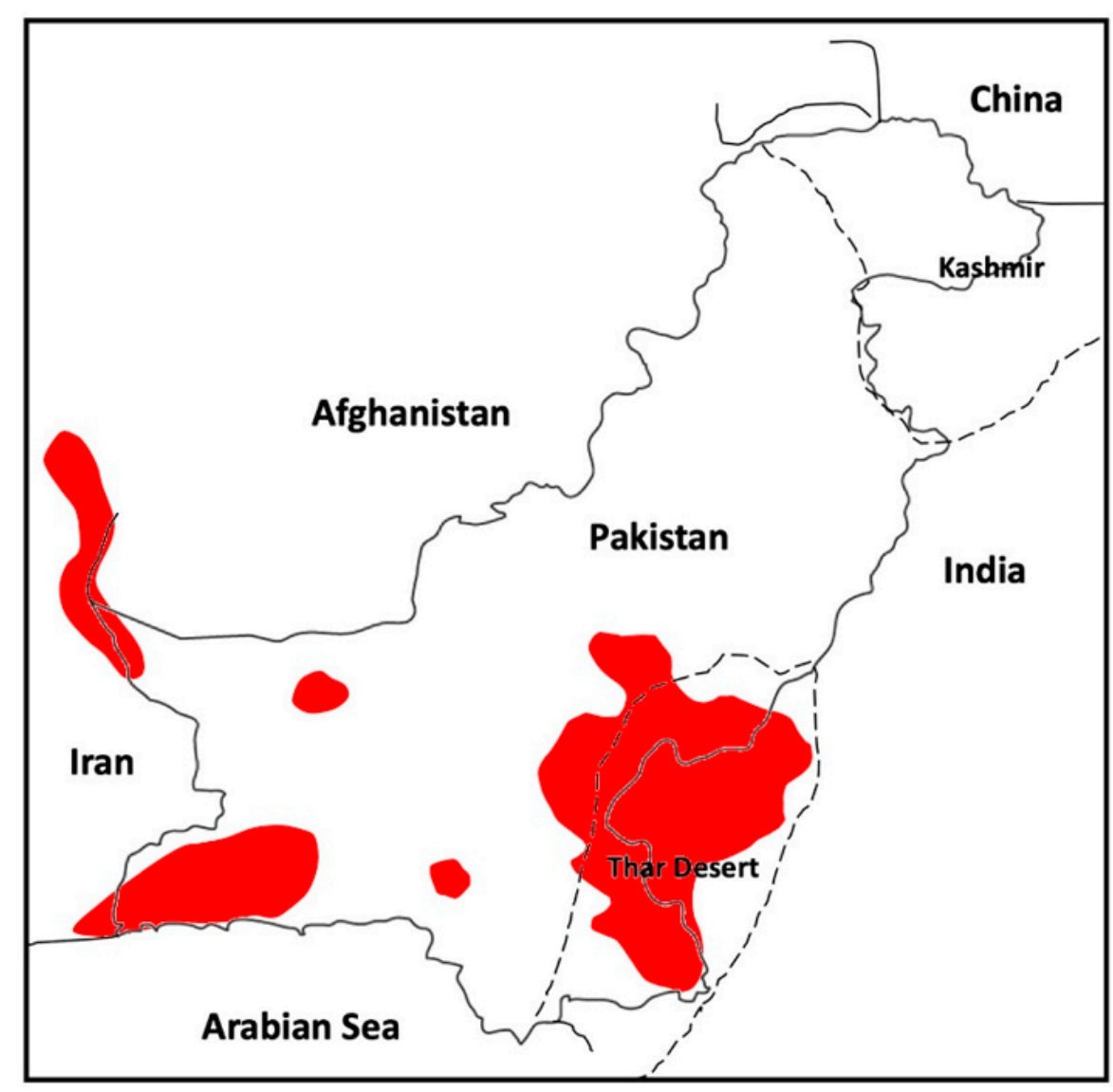

Figure 9. Locations and regions mentioned in the text in relation to desert locust activity and insecurity on the India-Pakistan border. Primary breeding areas in red.

Mali. Direct Insecurity. The Adrar des Iforas region of northern Mali (Figure 10) is an important desert locust breeding area [29], inhabited by the Tuareg people [57]. In the early 1990s, the Tuareg turned from occasional banditry [58] to rebellion [59]. Five Malian troops protecting a desert locust surveillance team were killed by Tuareg rebels in 1994 [8] and the insurrection restricted travel around breeding areas [7,8]. Desert locust operations in northern Mali were impeded relatively often through 2016 [4,18]. If gregarious desert locusts were to become active in Mali in the near future, surveillance and control operations might experience direct insecurity-related impediments. 


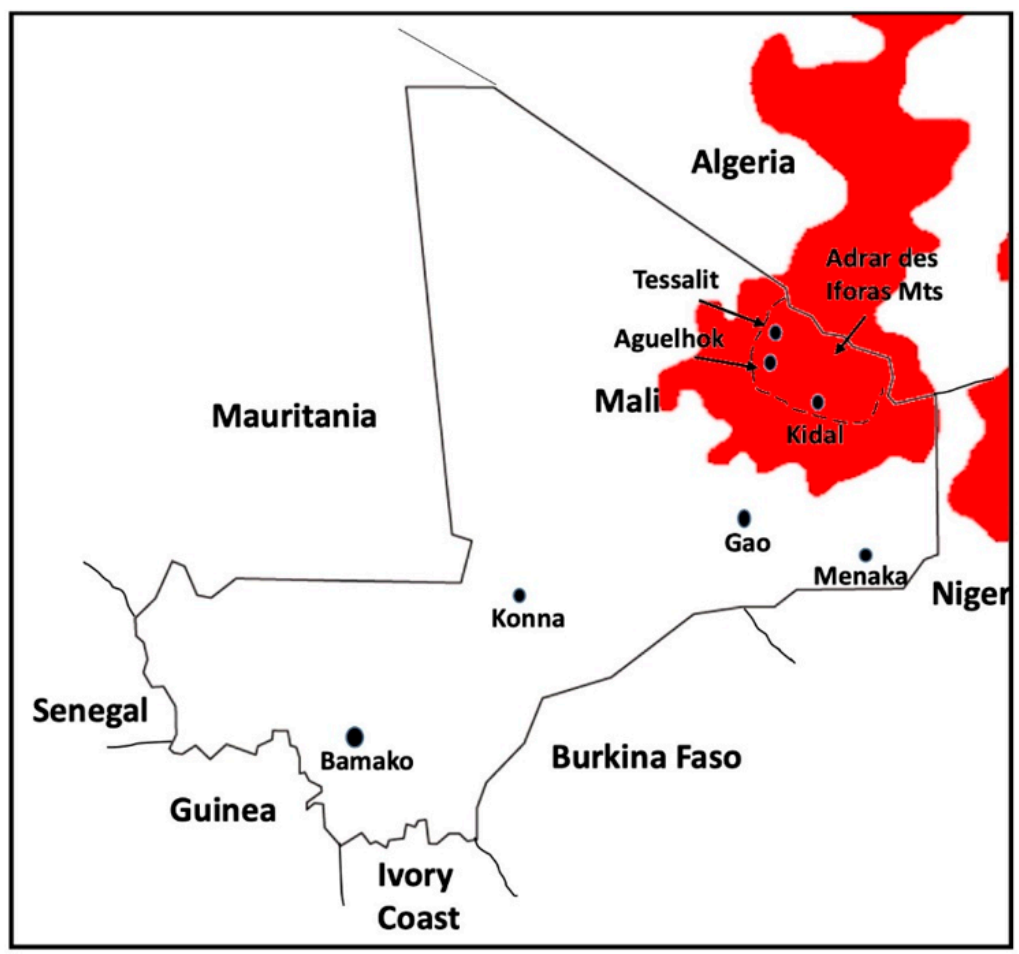

Figure 10. Locations and regions mentioned in the text in relation to desert locust activity and inScheme 2006. A Tuareg insurgency intensified when government army bases in Kidal, Menaka, and Tessalit (Figure 10) were attacked, but the conflict was resolved two months later $[59,60]$. In late 2011, another Tuareg rebellion began, strengthened by mercenaries from the Libyan civil war [59-61], and sporadic violent Tuareg unrest has continued through 2020.

Five Europeans were kidnapped by al-Qaeda in eastern and northern Mali in 2006, and a German tourist was killed [61]. A massacre of Malian troops and civilians at Aguelhok (Figure 10) occurred in early 2012, three of four military units in northern Mali defected to Malian National Liberation Army (MNLA) rebels, United States military airdrops supplied besieged Malian troops in Tessalit (Figure 10) [61], and Senegal sent troops to assist the Mali government [60]. A coup in March 2012, however, overthrew the government, collapsing military command, and the MNLA and Islamist Ansar al Din seized the north [61]. By April, the MNLA declared part of Mali a separate state, but it retreated after being ousted from the town of Gao (Figure 10) by a faction of al-Qaeda [61]. In early 2013, France attacked insurgents in the north after government forces were defeated in Konna and Bamako (Figure 10) [61]. While the impacts of indirect insecurity on desert locust operations have not been assessed, they are likely to be relatively substantial.

Mauritania. Direct Insecurity. The Mauritanian desert is mostly favorable to desert locust breeding [29], which occurred during the 1986-1989, 1992-1994, and the 2003-2005 desert locust episodes $[6,7,14]$. Although landmines had at times obstructed desert locust operations, they have largely been cleared or marked and have not interfered with desert locust control operations [4,62]. Intervention against desert locusts from 2007 to 2020 were reasonably effective [18].

Indirect Insecurity. In 1989-1991, racial tensions triggered ethnic violence that resulted in hundreds of deaths in Mauritania and in Senegal [63-65]. After those incidents, emphasis on conflict prevention and ethnic reconciliation has occurred with a number of constitutional amendments affirming the multiethnic character of the state [66]. Al-Qaeda killed four French tourists in 2007, launched attacks in Nouakchott, and conducted ransom kidnappings beginning in 2008 [65]. Border tensions involved Western Sahara and its Polisario separatist guerrillas [65]. Indirect insecurity probably has had a low to moderate effect on desert locust control capability. 
Niger. Direct Insecurity. A key desert locust breeding area encompasses the Aïr Mountains and the Tamesna region (Figure 11), which are inhabited by Tuareg. Tuareg insurrection hindered desert locust surveillance and control through 1994 [7]. In 1991, an encampment of scientists, including one of the authors (ML) researching desert locusts in the Tamesna was attacked by armed men, resulting in one casualty [67]. During 2007-2016, insecurity did not impede locust operations [4,18].

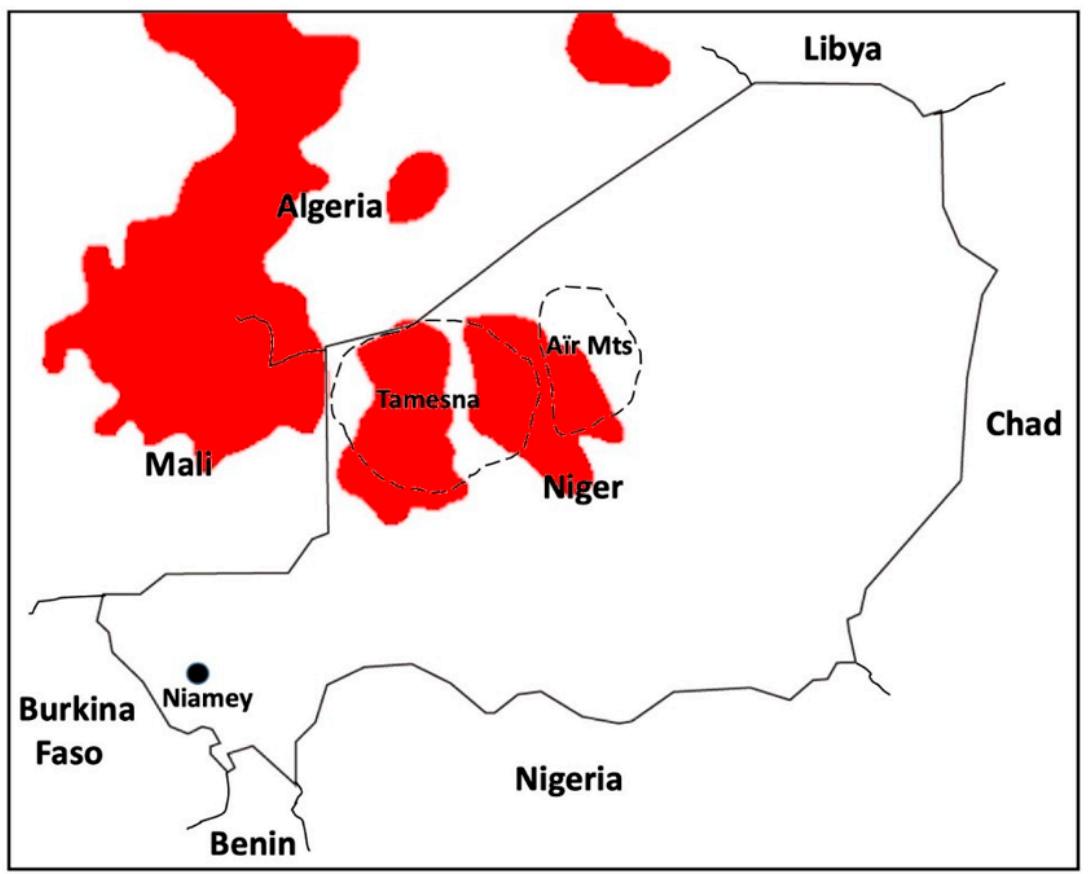

Figure 11. Locations and regions mentioned in the text in relation to desert locust activity and insecurity in Niger. Primary breeding areas in red.

Indirect Insecurity. While violent incidents were associated with Tuareg bandits and rebels, by the late 1990s insecurity was less tumultuous than in Mali because government responses were more accommodating [59], and some Tuareg groups laid down arms [68]. It appears likely that, were gregarious desert locust populations to develop or arrive in 2020, insecurity would not pose significant obstacles.

Saudi Arabia. Indirect Insecurity. Desert locust breeding in Saudi Arabia mainly occurs along the Tihama, the Rub al-Khali (Empty Quarter), and the north-central desert [29]. No direct insecurity regarding desert locust control has been reported. Despite Saudi Arabian involvement in external wars (i.e., Iraq, Kuwait, Yemen) and limited internal civil unrest and Islamic terrorism confined to cities, indirect insecurity has had a negligible impact on desert locust control.

Somalia. Direct Insecurity. Desert locust breeding mostly occurs in northern parts of Somalia, and these areas have been particularly problematic in 2020 [5,69]. National locust control capabilities were eliminated in Somalia, from the 1980s through 2020, because of armed conflict [70]; hence, desert locust surveillance during the late 1990s was conducted by one United Nations volunteer, a Somali counterpart in Hargeisa (Figure 12), and occasional FAO (Food and Agriculture Organization of the United Nations)-funded aerial missions by the Desert Locust Control Organization for Eastern Africa (DLCO-EA), based in Addis Ababa, Ethiopia (Figure 8) [8]. During the relatively limited 1997-1998 desert locust episode [15], swarms developed in Somaliland (Figure 12) and flew into Ethiopia's Ogaden region $[4,8]$. Direct insecurity has impeded desert locust operations in Somalia through 2020 [5], and Somalia is arguably the most problematic country with regard to insecurity in the desert locust's distribution. 


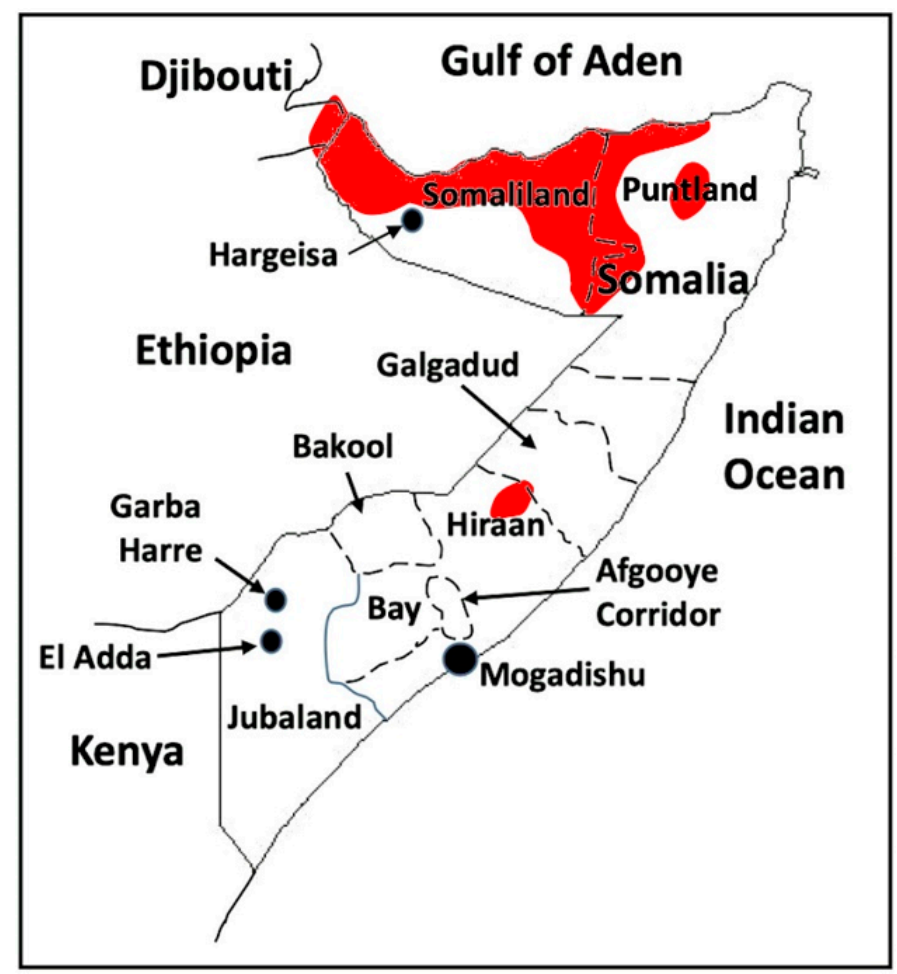

Figure 12. Locations and regions mentioned in the text in relation to desert locust activity and insecurity in Somalia. Primary breeding areas in red.

Indirect Insecurity. After the Somali president was ousted and Mogadishu (Figure 12) was captured by rebel militias in 1991, thousands of civilians became casualties and Somalia lost its central government [71,72]. In 1992, $\approx 350,000$ people died from disease, starvation, and civil war, prompting United States emergency aid airlifts [72-74]. In 1993, United States troops were deployed in Mogadishu to assist United Nations peacekeepers but heavy fighting resulted in 18 United States soldiers and $>500$ Somali fighters and civilians killed [72,75]. United States forces were withdrawn [74] and United Nations efforts to stabilize the government were aborted [75]. Puntaland and Jubaland (Figure 12) declared themselves as regional administrations in 1998 and factional fighting persisted after a transitional government was installed in 2000 [72,76]. A United Nations arms embargo on Somalia was in effect since the early 1990s, and in 2001-2002 Mogadishu was declared too dangerous for a United Nations office [72,77].

From 1996 through 1997, the al-Qaeda-linked Somali group, al-Ittihad, conducted attacks and bombings in Ethiopia. Starting in 1999, Ethiopia responded with incursions into southern Somalia to destroy al-Ittihad [78], capturing the regional capital of Garba Harre (Figure 12) [72]. In 2002, Ethiopian troops moved into Puntaland and, again, into southern Somalia [79-81]. Because the United States government suspected al-Qaeda activity in Somalia, military operations there increased [72]. An interim Somali government was formed in Kenya in 2003, and on moving to Somalia in 2005, internal divisions begat more violence [72]. Inter-militia fighting in Mogadishu during 2006 caused hundreds of civilian casualties and a militia-backed rival government, the Islamic Courts Union, seized most of southern Somalia and Mogadishu [72]. When Ethiopian troops re-invaded Somalia, Islamic government hard-liners declared jihad against Ethiopia, and subsequent fighting involved tanks and helicopters [72,82]. By 2007, the transitional government regained control, a United States airstrike killed the al-Shabaab insurgency's leader, and other airstrikes hit al-Qaeda targets in southern Somalia [72]. The government declared a state of emergency as fighting continued into 2008, including coordinated suicide bombings in semiautonomous regions [72]. 
By September 2011, >20 separate regional governments had developed across Somalia in addition to Puntaland and Somaliland (Figure 12), some warring against others [74]. Kenyan troops battled al-Shabaab in Somalia from late 2011 through 2016, and al-Shabaab claimed that it killed $\approx 100$ African Union soldiers in El-Adda (Figure 12) [74]. In October 2016, Ethiopia pulled its 2000 troops (part of a 22,000-strong African Union force, Figure 13) from four towns in southern Somalia which al-Shabaab captured within hours [83]. Widespread insecurity in Somalia has continued through 2020.

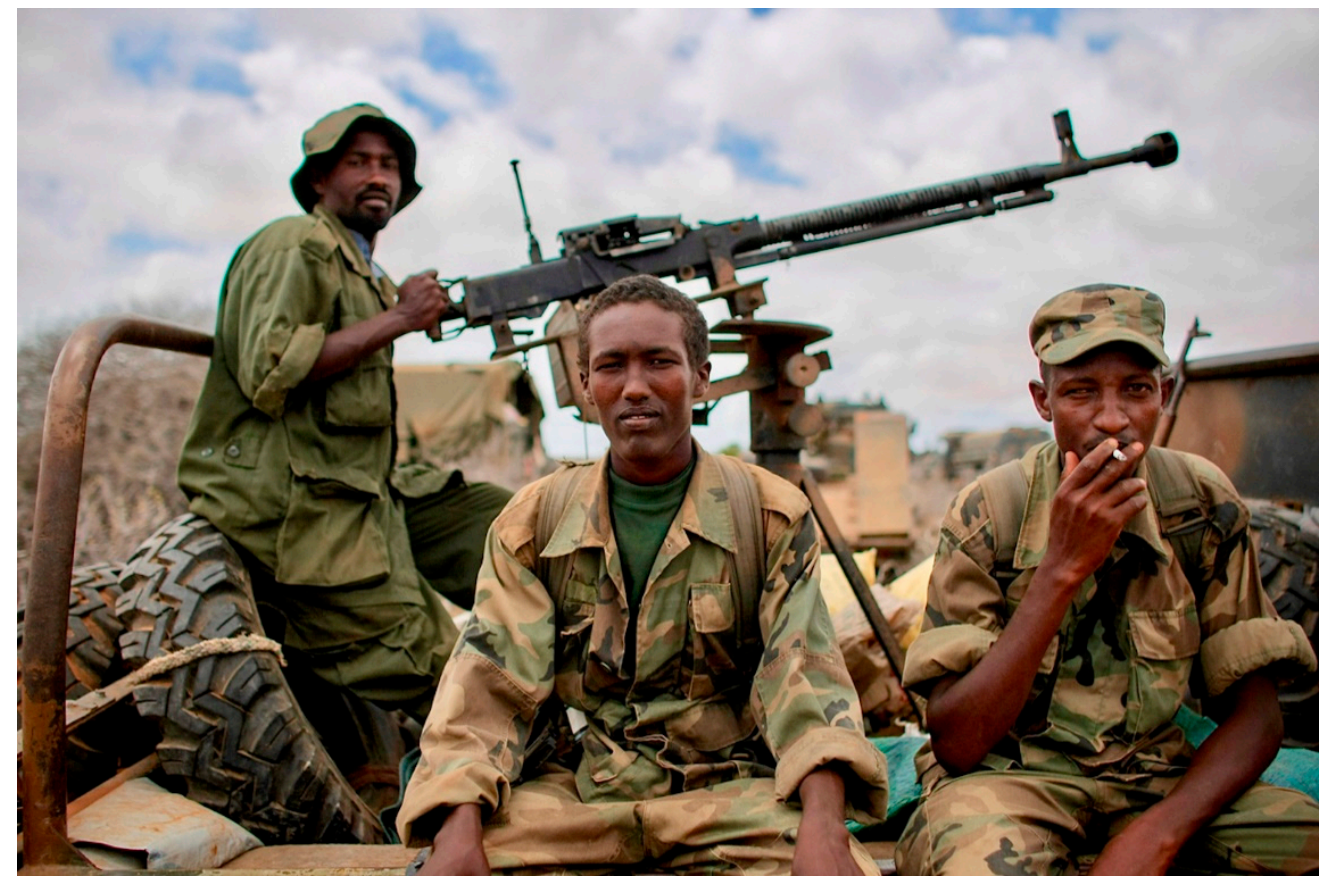

Figure 13. African Union Mission in Somalia (AMISOM) soldiers in Jubaland, Somalia, to combat insurgent militias; photo credit Stuart Price.

Over decades of conflict, thousands of landmines were scattered across parts of Somalia [84]. The Somalia-Ethiopia border and the regions of Galgadud, Bakool, Bay, Hiraan, and the Afgooye Corridor, and parts of Mogadishu (Figure 12) were the most heavily mined [84]. In addition to the instances of insecurity described above, regions of Somalia were also unsafe because of banditry and piracy. Indirect insecurity, like direct insecurity, continue to be major obstacles to desert locust control.

Sudan. Direct Insecurity. Sudan's Red Sea coastal plain, particularly the region from the Tokar Delta (Figure 14) to the Eritrean border, is a prolific desert locust breeding area [29]. Breeding also tends to occur in the western desert [29]. Civil war and insurgencies, especially around the Tokar Delta and Kassala [85] (Figure 14), impeded surveillance and control during the 1986-1989 plague. The Tokar Delta area was held by National Defense Alliance (Beja Congress) rebels in the 1990s and swarms developed there during the 1992-1994 upsurge and the 1997-1998 desert locust outbreak [4,15]. The northern coastal plain around Halaib (Figure 14) has been contested from 1986 to the present, by Egypt [86], rendering it off limits to locust scouts from both countries. Sudan is vulnerable to desert locust outbreaks becoming upsurges because direct insecurity persists in some breeding areas. 


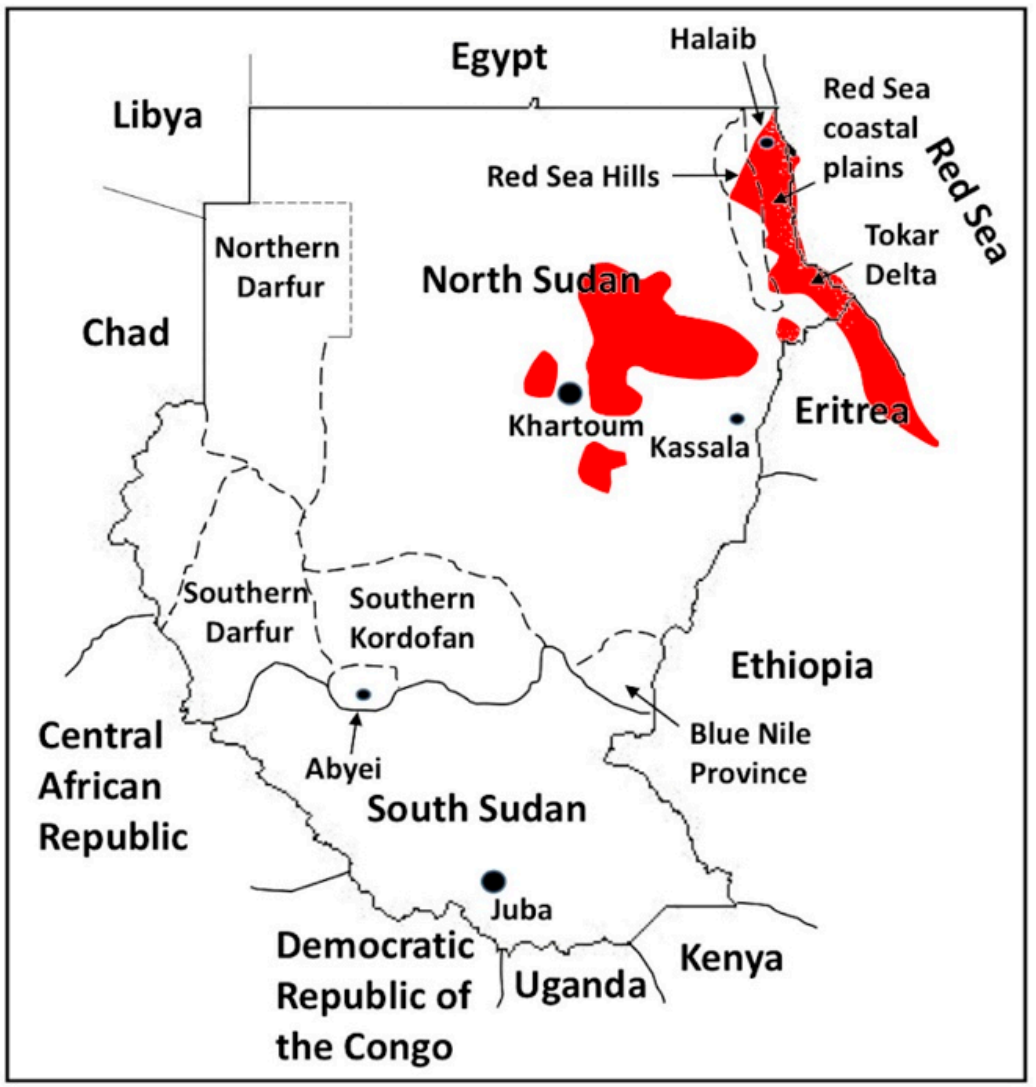

Figure 14. Locations and regions mentioned in the text in relation to desert locust activity and insecurity in North and South Sudan. Primary breeding areas in red.

Indirect Insecurity. The government also fought other rebel armies, mostly in the south, following Sudan's 1956 independence [87,88] through 2020; the largest rebel force was the 40,000-strong Sudan People's Liberation Army (SPLA) [89]. During peak war years, 2003-2005, the government attacked villages using helicopters and fixed-wing Antonov bombers [90]. Ground forces followed, targeting the Fur, Massalit, and Zaghawa tribes especially in the Darfur provinces (Figure 14) [90]. The military was augmented by the Janjaweed, a militia comprised of former bandits, demobilized soldiers, young tribesmen, and unemployed youths [90]. The aim was ethnic cleansing accomplished through atrocities, killing hundreds of thousands [70,91]. Less than a year after Sudan split into the Republic of (North) Sudan and the Republic of South Sudan (Figure 14) in 2005, the two countries were fighting again [88], and limited conflict in the Darfur provinces erupted into another civil war. Further, in April 2012, war recommenced between North Sudan and South Sudan, with the SPLA crossing into the north and the North Sudan Armed Forces bombing southern villages [88]. In addition, North Sudan fought insurgencies in the South Kordofan, Blue Nile, and Abyei provinces (Figure 14) [88]. Conflict also occurred within South Sudan against the Juba-based government (Figure 14) [88]. In 2014 the president of North Sudan renamed the Janjaweed the Rapid Support Forces (RSF), comprised of $\approx 10,000$ fighters, as his personal army to counter diminishing military loyalty [91]. The RSF continued inflicting atrocities, including aerial bombing of civilians in North and South Darfur, South Kordofan, and Blue Nile provinces (Figure 14) [91]. In 2016, in addition to its many other conflicts, the North Sudan government fought the Justice and Equality Movement, two different factions of the Sudan Liberation Movement, and the Liberation and Justice Movement [90]. 
Further, Sudan was cut off from international aid for harboring international terrorist cells, including al-Qaeda [8]; this was underscored by a 1997 United States missile strike on a "pharmaceutical factory" in Khartoum (Figure 14) suspected of manufacturing chemical weapons [8]. Despite the chronic and intense violence in Sudan that must certainly detract from optimal desert locust control capacity, and breeding areas compromised by direct insecurity, desert locust control operations in Sudan have been substantial and effective since 2003.

Western Sahara. Direct Insecurity. In 1988, a United States C-130 desert locust spray aircraft, flying from Senegal to Morocco, was downed by a shoulder-fired Polisario missile, killing the five-person crew [8]. Locust operations have been, at times, unfeasible in Western Sahara because of Polisario activity. During the 1986-1989, 1992-1994, and 2003-2005 control campaigns, swarms entering Western Sahara from Mauritania and Algeria could not be tracked until they crossed into Morocco or back into Algeria because of direct insecurity $[4,6,7,18]$. It is possible that direct insecurity will continue to be problematic for desert locust control for the foreseeable future.

Indirect Insecurity. Western Sahara (formerly Spanish Sahara), claimed by Morocco, has been vigorously contested by the Polisario Front since 1975 when Spain relinquished the territory [92,93]. The Polisario reported killing > 5000 Moroccan soldiers between 1982 and 1985 alone [53]. Many Polisario guerrillas took refuge in Algeria from Morocco's military [94], heightening tensions between Morocco and Algeria [8]. Additionally, the Polisario held 1360 Moroccan prisoners of war in Algeria as "bargaining chips", some of whom had been imprisoned for $>20$ years [94,95]. A United Nations-monitored ceasefire began in 1991, but Western Sahara's status has remained undecided (pending referendum), interspersed by ceasefire violations [53]. Insecurity also persisted when violent extremist groups emerged [96]. In 2010, Moroccan forces stormed a protest camp in Western Sahara, triggering violent demonstrations in the capital, Elayoun. In late 2011, three European aid workers were kidnapped from Polisario-administered refugee camps in Tindouf, Algeria (Figure 2), by the Movement for Unity and Jihad in West Africa (a faction of al-Qaeda) [96]. Polisario-Morocco tensions continued through 2016 and, although peace talks have been underway since 2018, tensions remain high and part of the country is held by the Polisario. Uncleared landmines constituted an additional source of persistent insecurity [97]. The continual conditions of insecurity, akin to Somalia, have stymied the development of a functional government that has crop protection capabilities. It is likely that, in Western Sahara, desert locust incursions and breeding will have to be controlled by external interventions (e.g., by Morocco, Mauritania, or cross-border multinational strike forces), assuming infested areas are accessible [6-8].

Yemen. Direct Insecurity. The two main Yemeni desert locust breeding areas are in the Tihama and Hadramawt regions (Figure 15) [29]. Insecurity in Yemen has resulted in a variety of obstacles to desert locust operations since 1986 [4]. The division of Yemen, in addition to chronic tribal conflicts, was partially responsible for exacerbating the 1986-1989 desert locust plague [8]. Tribal and clan frictions also impaired surveillance and control to a lesser extent during the 1992-1994 upsurge. Border conflicts with Saudi Arabia have impaired communication, travel, and desert locust surveillance on the border [8]. 


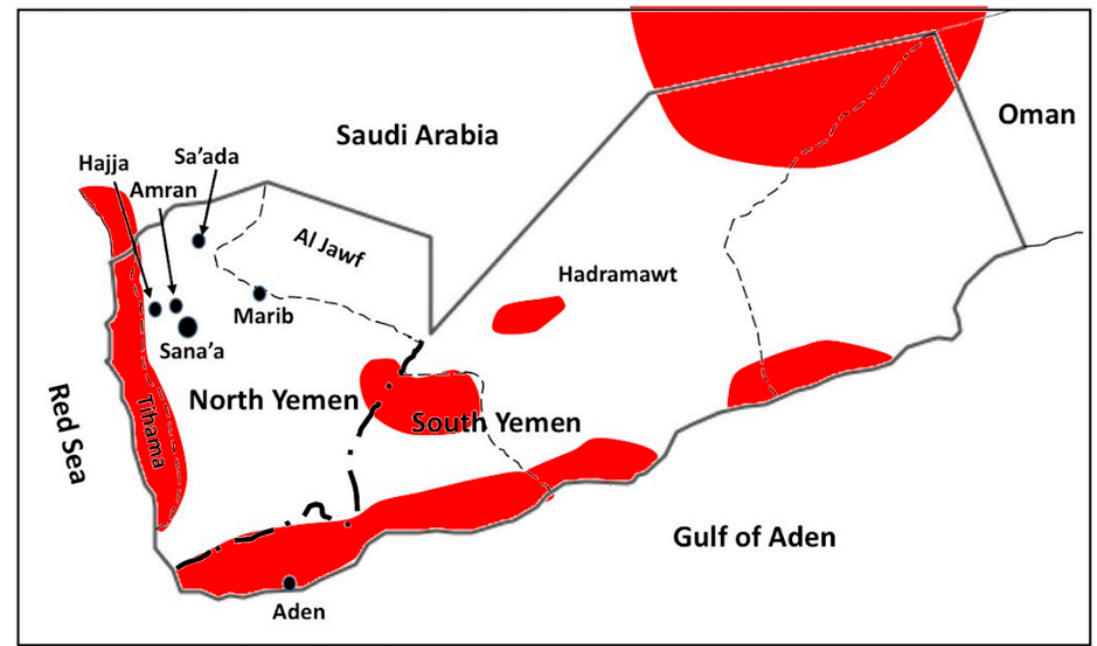

Figure 15. Locations and regions mentioned in the text in relation to desert locust activity and inScheme 1990. when traditionalist North Yemen and Marxist South Yemen (Figure 15) merged after years of skirmishing [98,99]. In mid-1994, a civil war erupted for several weeks, ending in defeat for separatist southern Yemen [99,100]. The war damaged infrastructure [100] and ministries were looted, including the ministry of agriculture, weakening Yemen's anti-locust capability [8]. North versus south enmity persisted $[100,101]$ through 2020.

There are $\approx 60$ million firearms in Yemen, nearly three per citizen [102]. Assault rifles, grenades, and light firearms were, into the 1990s, commonly sold from street stalls and at arms bazaars [102]. Long-standing animosities resulted in many inter-clan and anti-government clashes [98], and Yemeni clans often used foreign hostages to extort the government for funds and infrastructural improvements [103]. Tribal resistance [104-107], however, also intensified, involving surrounding and laying siege to Sana'a (Figure 15) in 2011 [108].

Chronic disputes over tribal homelands and national frontiers have afflicted Yemen since the 1930s [109]. As an example of border disputes, in 1998, Yemen alleged that Saudi Arabia violated its border 73 times over four weeks; transgressions included military deployments, shelling, and violations of air space and waters [8,110-113]. During 1999, a fundamentalist imam exhorted Muslims to kill all "infidels" in Yemen [8]. In 2000, al-Qaeda suicide bombers attacked the U.S.S. Cole in the Port of Aden (Figure 15) [8] and a French tanker [114]. The United States and Yemeni militaries struck at al-Qaeda by air and ground mainly in remote Marib and Hadramawt areas (Figure 15) [8,115]. In November 2002, a United States missile strike killed the leader of al-Qaeda in the Arabian Peninsula [100].

Mass protests in 2004 over myriad grievances led to arrests and military clashes with insurrectionists [100]. Emergent combatant groups in 2004 included the Houthis and the Believing Youth, and through 2016, six consecutive wars enveloped the Sa'ada, Hajja, Amran, and Al Jawf governorats (Figure 15), killing thousands [100,101].

The 2011 rise of Arab Spring resulted in President Saleh's removal in 2012, fracturing the army and the government [100]. Associated protests pitted civilians against law enforcement and military personnel, and many people were consequently attacked by activists and gangs $[100,116]$. Houthi rebels captured Sana'a (Figure 15) in September 2014 and the insurgency became a civil war [116]. The Houthis also battled al-Qaeda and Sunni Salafist movements [117].

In 2009, al-Qaeda called for an Islamic caliphate in Yemen [116] and seized territory in outlying provinces [118]. In March 2015, a Saudi-led military coalition (10 countries) intervened to defend the government against the Houthis and al-Qaeda and its affiliates $[116,117]$. By October, the coalition uprooted fighters of Zaydi Shiite Ansar Allah (Partisans of God) from most of southern Yemen, and the initial air campaign escalated into a ground conflict committing thousands of troops [118]. From March to October, $\approx 5000$ people were killed, 
including 2355 civilians and >150 coalition soldiers [118]; a Saudi airstrike (Figure 16) in September, for example, killed 80-130 civilians [118], and the United States launched airstrikes against al-Qaeda leaders [118]. In late September, Islamic State of Iraq and Syria (ISIS) suicide bombers killed 30 at a Sana'a mosque and battled against Houthis [118]. The conflicts seriously damaged Yemen's inadequate, already war-torn, infrastructure [117]. The conflicts have continued through 2020. Indirect insecurity has crippled Yemeni capacity and efforts to monitor and control desert locusts.

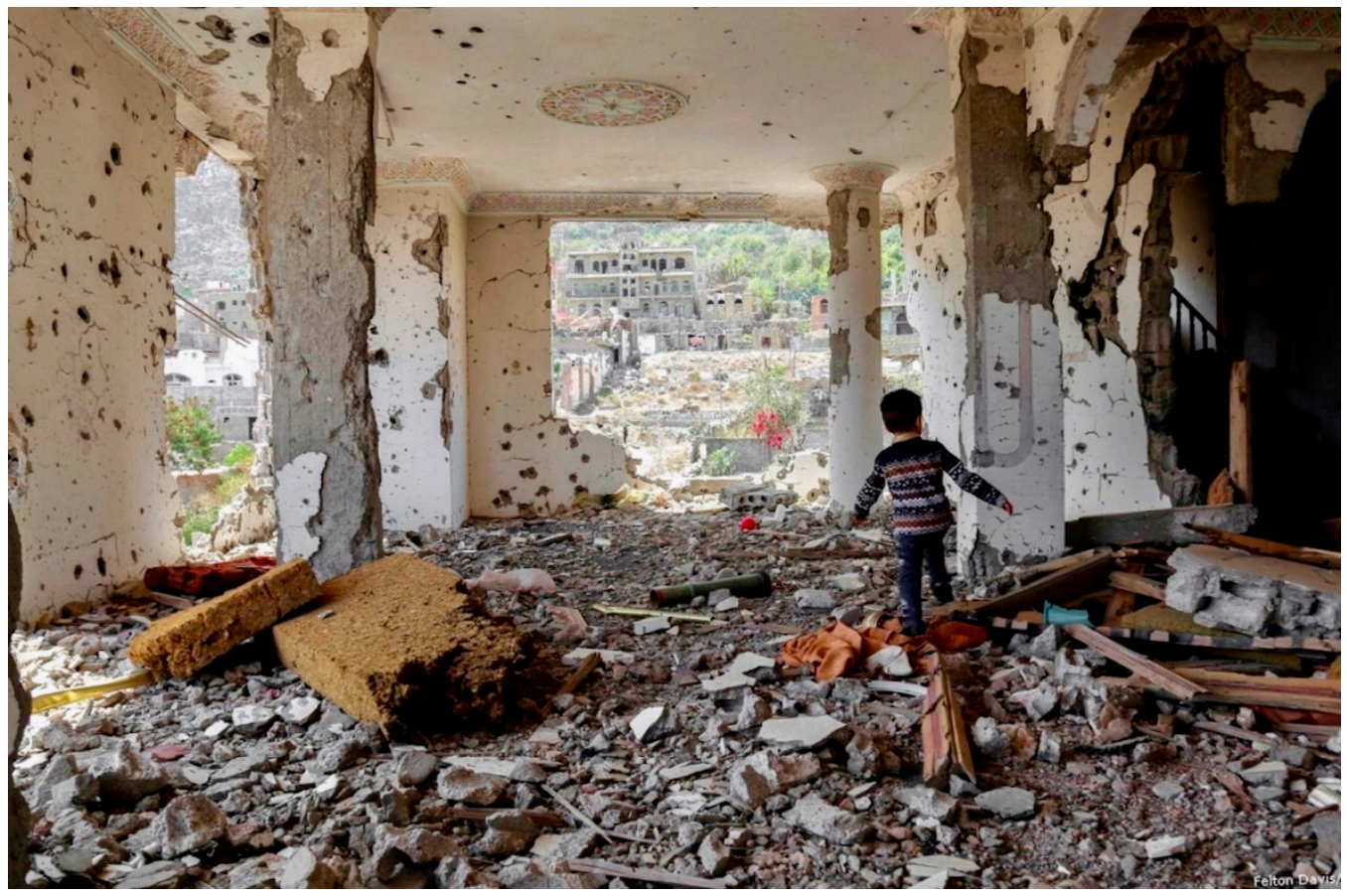

Figure 16. Yemeni child walks though rubble from Saudi/Emirati airstrike on Sana'a; photo credit Felton Davis/Flickr.

\section{Insecurity and the Recent Desert Locust Upsurge}

The most recent desert locust upsurge originated in the remote Rub al Khali, or Empty Quarter, of Saudi Arabia during the late spring and early summer of $2018[5,69,119,120]$. The outbreak was not detected until late 2018 when swarms moved into Yemen, countries of the Horn of Africa, and Egypt [5,121]. While Egypt, Eritrea, Ethiopia, and Sudan mounted substantial and largely effective control operations [5,121-132], Somalia and Yemen, both crippled by direct and indirect [active and inactive] effects of insurrection, insurgency, international and civil war, lawless interclan fighting, terrorism, and, in the instance of Somalia, landmines, were unable to conduct effective surveillance and control. After Saudi Arabia began combatting gregarious desert locust populations [121-138], Somalia and Yemen produced many swarms; from Somalia they moved into Kenya, Tanzania, Uganda, and Ethiopia, and from Yemen they invaded Oman, Iran, Pakistan, and India [swarms continued to escape from Saudi Arabia into Yemen, Oman, Iraq, Jordan, and other neighboring countries [5,121-138]. In all, $\geq 22$ countries in Africa and Asia were involved by May 2020, and $\approx 2.8$ million hectares were sprayed with insecticides [5]. While it would have been best to proactively intervene against the initial outbreak in the $R u b$ al Khali, possibly averting further intensification and dissemination of gregarious desert locust populations, efficacious control in Somalia and Yemen might also have had a pivotal impact on suppressing the upsurge [5]. Because of the effects of armed conflict, Somalia and Yemen became engines that continued to drive the upsurge further as Saudi Arabia, by May 2020, had treated $\approx 400,000$ ha, mitigating its role, to an extent, as a source [5]. 


\section{Insecurity and Possible Mitigation Measures}

Inaccessibility of desert locust breeding areas due to insecurity is generally an intractable challenge requiring political solutions rather than technological advances. Conflicts can be acute, long-term, fluid, and sporadic as they erupt, subside, spread, morph, and multiply. Reliable forecasting in neighboring countries will likely enable prepositioning of resources to control swarms when crossing borders from inaccessible areas. In the past, multinational teams, such as the now-defunct Maghrebian Strike Force [MSF], conducted cross-border operations when certain desert locust afflicted countries failed to do so [7]. The MSF was formed by the Commission de lutte contre le criquet pèlerin en Afrique du Nord-Ouest (CLCPANO) using Islamic Development Bank, FAO, and member country (Algeria, Libya, Mauritania, Morocco, Tunisia) funds [139]. Active in the early and mid-1990s, the MSF mostly operated in Mauritania and Mali [8]. The MSF, however, was as vulnerable to insecurity as national units. DLCO-EA also does not operate in war zones and most of its member countries (Djibouti, Eritrea, Ethiopia, Kenya, Somalia, South Sudan, Sudan, Tanzania, Uganda) have been in arrears [8], and other regional locust control organizations were nonfunctional or abolished [8]. A new mechanism, the Commission for Controlling the Desert Locust in the Western Africa Region (CLCPRO), established in 2016, makes a regional fund available for proactively controlling desert locust invasions, has been endowed with $\approx 6.5$ million dollars from its member countries (Algeria, Burkina Faso, Chad, Libya, Mali, Mauritania, Morocco, Niger, Senegal, and Tunisia) [5,140,141].

In situations where an outbreak developed in rebel-held territory adjoining a sympathetic country, covert cross-border cooperation has occurred $[4,8]$. Tensions between nations, however, might have increased if the collaboration was discovered, and further complicated if involved resources originated from international aid agencies.

In relatively recent years, the FAO's EMPRES program (Emergency Prevention System) in West and North Africa has proposed some approaches for dealing with insecurity. In the event of some forms of insecurity in a given area, the country should make efforts to ensure the safety of surveillance and control activities when possible, and, in consultation with the other countries of the region, establish reinforced surveillance in breeding areas of neighboring countries as a safeguard against possible desert locust swarm movement from the insecure area [142]. In addition, satellite imagery information on breeding conditions in the inaccessible areas is almost immediately available, making it possible to assess the probability of outbreaks and the value of strengthening surveillance in accessible breeding areas of neighboring countries [142]. As a contingency against actively developing gregarious desert locust episodes in insecure areas, emergency control plans for the existing national and regional systems can enable rapid response at lower cost compared to times when control systems and plans were not in place [142]. It has been suggested that desert locust survey teams should be comprised of indigenous personnel, familiar with the remote breeding areas, and with the consent and protection of local populations [142]. While the problem of insecurity has long been known, the recent desert locust episode demonstrates that this crucial aspect of desert locust management has not yet been sufficiently addressed.

\section{Conclusions}

While insecurity is mostly envisaged as a direct obstruction to surveillance and control operations, we suggest that insecurity is considerably more complex and crippling than direct obstruction. In 10 of the 13 countries (77\%) we cited as examples, insecurity, whether direct or indirect (Tables 1 and 2), occurred. Insecurity in some instances has been chronic, and diverse, often involving multiple simultaneous conflicts. Indirect, active and inactive, insecurity does not obviously impair surveillance and control, but the adverse impacts of indirect insecurity, although unmeasured, are likely substantial, particularly in countries with sever insecurity problems, such as, at present, Somalia, Yemen, Sudan, and possibly Chad. 
Table 1. Thirteen countries with major desert locust breeding areas, and where direct insecurity occurred during different time periods $[4-8,14,15,121-138]$.

\begin{tabular}{|c|c|c|c|c|c|}
\hline \multirow{2}{*}{$\begin{array}{l}\text { Countries with } \\
\text { Breeding Areas }\end{array}$} & \multicolumn{5}{|c|}{ Direct Insecurity $^{a}$} \\
\hline & $1986-1989^{b}$ & $1992-1994^{b}$ & $2003-2005^{b, c}$ & $2007-2016^{b}$ & $2018-2020^{b, d}$ \\
\hline Chad & $\sqrt{ }$ & & & & \\
\hline Eritrea & $\sqrt{ }$ & $\sqrt{ }$ & & & \\
\hline Ethiopia & & $\sqrt{ }$ & & & \\
\hline \multicolumn{6}{|l|}{ India, Pakistan } \\
\hline Mali & & $\sqrt{ }$ & & $\sqrt{ }$ & \\
\hline Mauritania & $\sqrt{ }$ & $\sqrt{ }$ & & & \\
\hline Niger & & $\sqrt{ }$ & & & \\
\hline \multicolumn{6}{|l|}{ Saudi Arabia } \\
\hline Somalia & $\sqrt{ }$ & $\sqrt{ }$ & & & $\sqrt{ }$ \\
\hline Sudan & $\sqrt{ }$ & $\sqrt{ }$ & & & \\
\hline Western Sahara & $\sqrt{ }$ & & & & \\
\hline Yemen & $\sqrt{ }$ & $\sqrt{ }$ & & $\sqrt{ }$ & $\sqrt{ }$ \\
\hline
\end{tabular}

a Includes areas made inaccessible because of land mines. ${ }^{b}$ 1986-1989 was a plague, 1992-1994 and 2003-2005 were upsurges, $2007-2016$ had no major desert locust episodes and many outbreaks, and 2018-2020 was an ongoing upsurge at the time of this writing. ${ }^{c}$ No reports of direct insecurity, 2003-2005; in July 2005, one area in Sudan was not accessible to ground surveillance due to "access difficulties" [143].

$\mathrm{d}$ This upsurge was ongoing at the time of this writing.

Table 2. Thirteen countries with major desert locust breeding areas, and where indirect insecurity occurred during different time periods.

\begin{tabular}{|c|c|c|c|c|c|}
\hline \multirow{2}{*}{$\begin{array}{l}\text { Countries with } \\
\text { Breeding Areas }\end{array}$} & \multicolumn{5}{|c|}{ Indirect Insecurity $^{a}$} \\
\hline & $1986-1989^{d}$ & $1992-1994^{d}$ & $2003-2005^{d}$ & $2007-2016^{d}$ & $2018-2020^{d}$ \\
\hline Chad & $\sqrt{ }$ & $\sqrt{ }$ & $\sqrt{ }$ & $\sqrt{ }$ & $\sqrt{ }$ \\
\hline Eritrea & $\sqrt{ }$ & $\sqrt{ }$ & $\sqrt{ }$ & & \\
\hline Ethiopia & $\sqrt{ }$ & $\sqrt{ }$ & $\sqrt{ }$ & $\sqrt{ }$ & $\sqrt{ }$ \\
\hline \multicolumn{6}{|l|}{ India, Pakistan ${ }^{b}$} \\
\hline Mali & $\sqrt{ }$ & $\sqrt{ }$ & $\sqrt{ }$ & $\sqrt{ }$ & $\sqrt{ }$ \\
\hline Mauritania & $\sqrt{ }$ & $\sqrt{ }$ & & & \\
\hline Niger & $\sqrt{ }$ & $\sqrt{ }$ & & & \\
\hline \multicolumn{6}{|l|}{ Saudi Arabia ${ }^{c}$} \\
\hline Somalia & $\sqrt{ }$ & $\sqrt{ }$ & $\sqrt{ }$ & $\sqrt{ }$ & $\sqrt{ }$ \\
\hline Sudan & $\sqrt{ }$ & $\sqrt{ }$ & $\sqrt{ }$ & $\sqrt{ }$ & $\sqrt{ }$ \\
\hline Western Sahara & $\sqrt{ }$ & $\sqrt{ }$ & $\sqrt{ }$ & $\sqrt{ }$ & \\
\hline Yemen & $\sqrt{ }$ & $\sqrt{ }$ & $\sqrt{ }$ & $\sqrt{ }$ & $\sqrt{ }$ \\
\hline
\end{tabular}

${ }^{a}$ Both active and inactive indirect insecurity. ${ }^{b}$ India and Pakistan desert locust control capacities were likely not impaired by the Kashmir conflict [8]. ' Despite Saudi Arabia's involvement in its ongoing war with Yemen, desert locust control capacity was likely not impaired. d 1986-1989 was a plague, 1992-1994 and 2003-2005 were upsurges, 2007-2016 had no major desert locust episodes and many outbreaks, and 2018-2020 was an ongoing upsurge at the time of this writing.

The challenge of insecurity on grand, varied, and complex scales presents a unique obstacle to desert locust control in breeding areas. Further, other desert locust afflicted countries are also beset by insecurity (e.g., Afghanistan, Iraq, Libya, Syria). While some desert locust scenarios might be managed within conflict zones through one creative means or another, operations will likely continue to be impeded and thwarted by insecurity. 
Impediments posed by insecurity must be better taken into account for desert locust risk management planning, and realistic mitigation measures must be carefully designed and implemented.

Author Contributions: A.T.S. conceived the article and drafted the manuscript with substantial input from M.L. All authors have read and agreed to the published version of the manuscript.

Funding: This research received no external funding.

Conflicts of Interest: The authors declare no conflict of interest.

Disclaimer on Maps: The designations employed and the presentation of material in the maps do not imply the expression of any opinion on the parts of the U.S. Department of Agriculture and Agronomy concerning the legal or constitutional status of any country, territory or sea area, or concerning the delimitation of frontiers.

Mention of trade names or commercial products in this publication is solely for the purpose of providing specific information and does not imply recommendation or endorsement by the U.S. Department of Agriculture. USDA is an equal opportunity provider and employer.

\section{References}

1. Lecoq, M.; Zhang, L. Encyclopedia of Pest Orthoptera of the World; China Agricultural University Press: Beijing, China, 2019.

2. Babah, M.A.O. Strategy for controlling the desert locust in Mauritania. In New Strategies in Locust Control; Krall, S., Peveling, R., Ba Diallo, D., Eds.; Birkhauser: Berlin, Germany, 1997; pp. 487-491.

3. Showler, A.T. Proaction: Strategic framework for today's reality. In New Strategies in Locust Control; Krall, S., Peveling, R., Ba Diallo, D., Eds.; Birkhauser: Berlin, Germany, 1997; pp. 461-465.

4. Showler, A.T. Desert locust control: The effectiveness of proactive interventions and the goal of outbreak prevention. Am. Entomol. 2018, 65, 180-191. [CrossRef]

5. Showler, A.T.; Babah, M.A.O.; Lecoq, M.; Maeno, K. Early intervention against desert locusts: Current proactive approach and the possibility of sustainable outbreak prevention. Agronomy 2021. (submitted).

6. Showler, A.T.; Potter, C.S. Synopsis of the desert locust, Schistocerca gregaria (Forskål), plague 1986-1989 and the concept of strategic control. Am. Entomol. 1991, 37, 106-110. [CrossRef]

7. Showler, A.T. Locust (Orthoptera: Acrididae) outbreak in Africa and Asia, 1992-1994. Am. Entomol. 1995, 41, 179-185. [CrossRef]

8. Showler, A.T. The importance of armed conflict to desert locust control, 1986-2002. J. Orthopt. Res. 2003, 12, 127-133. [CrossRef]

9. Steedman, A. Locust Handbook; Overseas Development Natural Resources Institute: London, UK, 1988.

10. Cossé, O.; Lazar, M.; Hassane, S. Rapport de l'Evaluation à mi-Parcours du Programme EMPRES Composante Criquet Pèlerin en Région Occidentale; Food and Agriculture Organization of the United Nations: Rome, Italy, 2009.

11. Lecoq, M. Vers une solution durable au problème du criquet pèlerin? Science Chang. Planétaires/Sécheresse 2004, 15, 217-224.

12. Sword, G.A.; Lecoq, M.; Simpson, S.J. Phase polymorphism and preventative locust management. J. Insect Physiol. 2010, 56, 949-957. [CrossRef] [PubMed]

13. France Diplomatie Home Page. Available online: https://www.diplomatie.gouv.fr/fr/ (accessed on 20 October 2020).

14. Belayneh, Y.T. Acridid pest management in the developing world: A challenge to the rural population, a dilemma to the international community. J. Orthopt. Res. 2005, 14, 187-195. [CrossRef]

15. Showler, A.T. A summary of control strategies for the desert locust, Schistocerca gregaria (Forskål). Agric. Ecosyst. Environ. 2002, 90, 97-103. [CrossRef]

16. Lecoq, M. Desert locust management: From ecology to anthropology. J. Orthopt. Res. 2005, 14, 179-186. [CrossRef]

17. Gay, P.M.; Lecoq, M.; Piou, C. Improving preventive locust management: Insights from a multi-agent model. Pest Manag. Sci. 2018, 74, 46-58. [CrossRef] [PubMed]

18. FAO (Food and Agriculture Organization of the United Nations). Desert Locust Watch. Available online: http://www.fao.org/ ag/locusts/en/info/info/indiz/html (accessed on 23 October 2020).

19. Roberts, H. The Battlefield: Algeria 1988-2002, Studies in a Broken Polity; Verso Books: London, UK, 2003.

20. Algeria Hit by Two Massacres. Available online: http:/ / news.bbc.co.uk/2/hi/middle_east/1963518.stm (accessed on 20 October 2020).

21. Mellah, S. The massacres in Algeria, 1992-2004. In Proceedings of the 32nd Session of the Permanent Peoples' Tribunal on Human Rights Violation in Algeria (1992-2004), Paris, France, 5-8 November 2004.

22. Strachan, M.L. Conflict Analysis of Algeria; Governance Social Development Humanitarian Conflict, Applied Knowledge Services: Washington, DC, USA, 2014.

23. Algeria Profile-Timeline. Available online: https://www.bbc.com/news/world-africa-14118856 (accessed on 24 October 2020).

24. Jesus, C.E. Terrorism financing: The particular case of al-Qaeda in the Islamic Maghreb (AQIM). Afr. J. Prev. Combat. Terror. 2011, 2, 39-59. 
25. Boukhars, A. What's next for Mali and Algeria? Available online: http:/ / carnegieendowment.org/2013/01/23/what-s-next-formali-and-algeria/f4sl (accessed on 6 January 2021).

26. Spencer, C. Strategic posture review: Algeria. Available online: http://www.chathamhouse.org/sites/default/files/public/ Research/Middle\%20East/0712wpr_spencer.pdf (accessed on 20 October 2020).

27. Ammour, L.A. Regional Security Cooperation in the Maghreb and Sahel: Algeria's Pivotal Ambivalence; Africa security brief no. 18; African Center for Strategic Studies: Washington, DC, USA, 2012.

28. Raleigh, C.; Dowd, C. Real-Time Analysis of African Political Violence. Conflict Trends No. 11. Available online: http: //www.acleddata.com/wp-content/uploads/2013/02/ACLED-Conflict-Trends-Report-No.-11-February-2013.pdf (accessed on 20 October 2020).

29. Pedgley, D. Desert Locust Forecasting Manual; Centre for Overseas Pest Research: London, UK, 1981.

30. Kayalto, M.; Idrissi Hassani, M.; Lecoq, M.; Gay, P.F.; Piou, C. Cartographie des zones de reproduction et de grégarisation du criquet pèlerin au Tchad. Cah. Agric. 2020, 29, 14. [CrossRef]

31. Collins, R.O.; Burr, M.I.; Burr, M. Africa's Thirty Years' War: Libya, Chad, and the Sudan 1963-1993; Westview Press: Boulder, CO, USA, 1999.

32. More Clashes in Northern Chad. Available online: http://news.bbc.co.uk/2/hi/africa/1092482.stm (accessed on 20 October 2020).

33. Mine Wounds Chad Rebel Leader. Available online: http://news.bbc.co.uk/2/hi/africa/2225280.stm (accessed on 20 October 2020).

34. Chad profile-Timeline. Available online: https://www.bbc.com/news/world-africa-13164690 (accessed on 24 October 2020).

35. Chad Peace Deal Signed. Available online: http://news.bbc.co.uk/2/hi/africa/1747940.stm (accessed on 14 October 2020).

36. Berg, P. The Dynamics of Conflict in the Tri-Border Region of the Sudan, Chad and the Central African Republic; Friedrich Ebert Foundation: Berlin, Germany, 2008.

37. Ploch, L. Instability and Humanitarian Conditions in Chad; CRS report for Congress; Congressional Research Service: Washington, DC, USA, 2010.

38. Clash on Chad-CAR Border. Available online: http://news.bbc.co.uk/2/hi/africa/2177926.stm (accessed on 20 October 2020).

39. Papstein, R. Eritrea: Revolution at Dusk; The Red Sea Press: Trenton, NJ, USA, 1991.

40. Bereketeab, R. The complex roots of the second Eritrea-Ethiopia war: Re-examining the causes. Afr. J. Int. Aff. 2013, 13, 15-59.

41. Sudan and Eritrea in Reconciliation Talks. Available online: http://news.bbc.co.uk/2/hi/africa/839356.stm (accessed on 20 October 2020).

42. Sudan and Eritrea Begin Repairing Relations. Available online: http://news.bbc.co.uk/2/hi/africa/590910.stm (accessed on 20 October 2020).

43. Kwiatkowska, B. The Eritrea/Yemen arbitration: Landmark progress in the acquisition of territorial sovereignty and equitable maritime boundary delimitation. Boundary Secur. Bull. 2000, 8, 66-86. [CrossRef]

44. United Nations Mission in Ethiopia and Eritrea. Available online: https://peacekeeping.un.org/en/mission/past/unmee (accessed on 29 October 2020).

45. Young, J. Beja: Local Conflict, Marginalization, and the Threat to Regional Security; Institute for Security Studies: Pretoria, South Africa, 2011.

46. Ethiopia Profile-Timeline. Available online: https://www.bbc.com/news/world-africa-13351397 (accessed on 24 October 2020).

47. Ethiopia Says Foils Somali Rebel Plot to Seize U.N. Staff. Available online: https:/ / news.trust.org/item/20130325200500-jfusq/ (accessed on 20 October 2020).

48. Recent Landmine Use by India and Pakistan. Available online: https://www.hrw.org/report/2002/05/22/recent-landmine-useindia-and-pakistan (accessed on 20 October 2020).

49. Ganguly, S. Conflict Unending: India and Pakistan; Columbia University Press: New York, NY, USA, 2002.

50. Jones, O.B. Pakistan; Yale University Press: New Haven, CT, USA, 2002.

51. India and Pakistan: Tense Neighbors. Available online: http://news.bbc.co.uk/2/hi/south_asia/102201.stm (accessed on 20 October 2020).

52. Kashmir Conflict: Tension on the India Pakistan Border. Available online: https://www.bbc.com/news/world-asia-37531900 (accessed on 24 October 2020).

53. Morocco Profile-Timeline. Available online: https://www.bbc.com/news/world-africa-14123260 (accessed on 24 October 2020).

54. Kashmir: Pakistan Call Emergency Meeting Amid ‘Deteriorating Situation'. Available online: http://www.cnn.com/2016/09/29 /homepage2/kashmir-pakistani-soldiers-killed-india-surgical-strikes (accessed on 23 October 2020).

55. Marszal, A. India Build Underground Bunkers on Kashmir Frontier as Border Clashes with Pakistan Escalate. Available online: http:/ / www.telegraph.co.uk/news/2016/10/04/india-builds-underground-bunkers-on-kashmir-frontier-as-borderclashes-with-pakistan-escalate (accessed on 20 October 2020).

56. Le Miere, J. India-Pakistan War Timeline: Recent Deadly Attacks Are Just the Latest Between Nuclear Neighbors. Available online: http:/ / www.ibtimes.com/india-pakistan-war-timeline-recent-deadly-attacks-are-just-latest-between-nuclear-neighbors (accessed on 20 October 2020).

57. Nicolaisen, J.; Nicolaisen, I. The Pastoral Tuareg: Ecology, Culture, and Society; Thames \& Hudson: London, UK, 1997. 
58. Malian Tuaregs Accused of Killings in Niger. Available online: http://news.bbc.co.uk/2/hi/africa/123742.stm (accessed on 23 October 2020).

59. Ba, O. Tuareg Nationalism and Cyclical Pattern of Rebellions: How the Past and Present Explain Each Other; Sahel Research Group, Working Paper 007; University of Florida: Gainesville, FL, USA, 2014.

60. Brahim, E.O. Conflict in Northern Mali: Internal Facts and Regional Impacts. Available online: https://studies.aljazeera.net/en/ reports/2012/02/2012219113630111169.html (accessed on 20 October 2020).

61. Arieff, A. Crisis in Mali; R42664; Congressional Research Service: Washington, DC, USA, 2013.

62. Mauritania Declares Itself Landmine Free Nearly Two Decades After Mine Clearance Began. Available online: https:// reliefweb.int/report/mauritania/mauritania-declares-itself-landmine-free-nearly-two-decades-after-mine-clearance (accessed on 8 November 2020).

63. Fievet, J.-L. Senegalese-Mauritanian Riots Spread. Available online: http://www.washingtonpost.com/archive/politics/198904 /29/senegalese-mauritanian-riots-spread/54125c6fa-4815-bdfe-c4ab4db2482c/ (accessed on 8 November 2020).

64. Ethnic Riots Spread across Senegal border. Available online: http://www.chicagotribune.com/news/et-xpm-1989-05-01-89040 80799-story.html (accessed on 8 November 2020).

65. Rao, S. Conflict Analysis of Mauritania; Governance, Social Development, Humanitarian, Conflict Applied Knowledge Services, University of Birmingham: Birmingham, UK, 2014.

66. Boukhars, A. The Drivers of Insecurity in Mauritania. Available online: https://carnegieendowment.org/2012/04/30/driversof-insecurity-in-mauritania-pub-47955 (accessed on 8 November 2020).

67. Chouvenc, H. Pilote de Brousse; Editions du Miroir: Montvicq, France, 1998.

68. Chronology for Tuareg in Niger. Minorities at Risk Project. Available online: https://www.refworld.org/docid/469f38c2104.html (accessed on 23 October 2020).

69. Current Upsurge (2019-2020). Available online: http://www.fao.org/ag/locusts/en/info/info/indiz/html (accessed on 23 October 2020).

70. Desert Locusts Ravage Breakaway Somalia Region. Available online: http://www.earthweek.com/2009/ew090612/ew090612c. html (accessed on 20 October 2020).

71. Peterson, S. Me Against My Brother, at War in Somalia, Sudan and Rwanda; Routledge Press: New York, NY, USA, 2000.

72. Hogg, A.L. Timeline: Somalia, 1991-2008. From Troubled to Dire. Available online: http://www.theatlantic.com/magazine/ archive/2008/12/timeline-somalia-1991-2008/307190 (accessed on 23 October 2020).

73. Country profile-Somalia. Available online: https://www.bbc.com/news/world-africa-14094503 (accessed on 23 October 2020).

74. Somalia Civil War. Available online: https://www.globalsecurity.org/military/world/war/somalia.htm (accessed on 23 October 2020).

75. Bowden, M. Black Hawk Down; Signet: New York, NY, USA, 1999.

76. Factional Fighting Erupts in Somalia. Available online: http://news.bbc.co.uk/2/hi/africa/2146701.stm (accessed on 20 October 2020).

77. Somalia: General Overview of the Security Situation in the City of MOGADISHU (2000-2002). Available online: https: / www. refworld.org/docid/3f7d4e1f2a.html (accessed on 23 October 2020).

78. Somalia's Role in Terror. Available online: http://news.bbc.co.uk/2/hi/africa/1723586.stm (accessed on 20 October 2020).

79. Ethiopian Troops Deploy in Somalia. Available online: http://news.bbc.co.uk/2/hi/africa/1747396.stm (accessed on 20 October 2020).

80. Ethiopian Troops in Somalia. Available online: http:/ /news.bbc.co.uk/2/hi/africa/1989954.stm (accessed on 20 October 2020).

81. U.S. Watches Somali al-Qaeda Links. Available online: http://news.bbc.co.uk/2/hi/africa/1877878.stm (accessed on 24 October 2020).

82. Somali Rebels Shoot Down Ethiopian Helicopter as Clashes Worsen. Available online: https://www.pbs.org/newshour/nation/ africa-jan-june07-somalia_03-30 (accessed on 20 October 2020).

83. Somalia's al-Shabaab in Comeback, as Ethiopia Pulls Troops. Available online: http://www.foxnews.com/world/2016/10/27 / somalia-al-shabab-in-comeback-as-ethiopia-pulls-troops (accessed on 20 October 2020).

84. Landmine Danger Persists in Somalia. Available online: https://www.thenewhumanitarian.org/news/2013/02/01/landminedanger-persists-somalia (accessed on 20 October 2020).

85. Kassala in Government Hands. Available online: http://news.bbc.co.uk/2/hi/africa/1014872.stm (accessed on 20 October 2020).

86. Mohyeldeen, S. The Egypt-Sudan Border: A Story of Unfulfilled Promise; Carnegie Endowment for International Peace: Washington, DC, USA, 2020.

87. Country Profile-Sudan. Available online: https:/ /www.bbc.com/news/world-africa-14094995 (accessed on 23 October 2020).

88. Ottaway, M.; El-Sadany, M. Sudan: From Conflict to Conflict; The Carnegie Papers, Carnegie Endowment for International Peace: Washington, DC, USA, 2012.

89. Salopek, P. Shattered Sudan: Drilling for oil, hoping for peace. Nat. Geograph. 2003, 203, 30-59.

90. Rothbart, D.; Yousif, A. Ideology and Cultural Violence in Darfur. Available online: https:/ /www.accord.org.za/conflict-trends/ ideology-cultural-violence-darfur/ (accessed on 20 October 2020).

91. Adam, A.H. In Sudan, the Janjaweed Rides Again. Available online: https://www.nytimes.com.2014/07/17/opinion/in-sudanthe-janjaweed-rides-again.html (accessed on 6 January 2021). 
92. Polisario Rejects UN Peace Plan. Available online: http://news.bbc.co.uk/2/hi/africa/1547452.stm (accessed on 20 October 2020).

93. Polisario Blasts Morocco's Sahara Claim. Available online: http://news.bbc.co.uk/2/hi/africa/1857421.stm (accessed on 20 October 2020).

94. Sahara Conflict Drags On. Available online: http://news.bbc.co.uk/2/hi/africa/1191810.stm (accessed on 20 October 2020).

95. Morocco Dismisses POW Move. Available online: http://news.bbc.co.uk/2/hi/africa/2052019.stm (accessed on 20 October 2020).

96. Arieff, A. Western Sahara; RS20962; Congressional Research Service: Washington, DC, USA, 2014. Available online: https: / / fas.org/sgp/crs/row/RS20962.pdf (accessed on 20 October 2020).

97. United Nations Security Council. Report of the Secretary-General on the Situation Concerning Western Sahara; S/2008/251; United Nations Security Council: New York, NY, USA, 2008; Available online: https://digitallibrary.un.org/record/624602?ln=fr (accessed on 20 October 2020).

98. Dresch, P. A History of Modern Yemen; Cambridge University Press: Cambridge, UK, 2001.

99. Country Profile: Yemen. Available online: https://www.bbc.com/news/world-middle-east-14704852 (accessed on 23 October 2020).

100. Lewis, A. Violence in Yemen: Thinking about violence in fragile states beyond the confines of conflict and terrorism. Stab. Int. J. Secur. Dev. 2013, 2, 13. [CrossRef]

101. Key Facts about the War in Yemen. Available online: httpps://www.aljazeera.com/news/2018/3/25/key-facts-about-the-warin-yemen (accessed on 6 January 2021).

102. Yemen's Weapon Culture. Available online: http://news.bbc.co.uk/2/hi/middle_east/1775938.stm (accessed on 24 October 2020).

103. Kidnapping of Foreigners in Yemen, 1996-2001. Available online: https://al-bab.com/kidnapping-foreigners-yemen-1996-2001 (accessed on 6 January 2021).

104. Britons Unlawfully Killed in Yemen. Available online: http://news.bbc.co.uk/2/hi/uk_news/542899.stm (accessed on 20 October 2020).

105. Eight Die in Yemen Tribal Clash. Available online: http://news.bbc.co.uk/2/hi/middle_east/373554.stm (accessed on 23 October 2020).

106. Yemen: Arabia's Wild West. Available online: http://news.bbc.co.uk/2/hi/programmes/from_our_own_correspondent/253004 .stm (accessed on 20 October 2020).

107. Yemen Troops Surround Two Villages. Available online: http://news.bbc.co.uk/2/hi/middle_east/521018.stm (accessed on 20 October 2020).

108. Schmitz, C. The Rise of Yemen's Houthi Rebels. Available online: https://www.bbc.com/news/world-middle-east-31645145 (accessed on 20 October 2020).

109. Smith, G.R.Y.; Auchterlonie, P. Yemen, 2nd ed.; ABC-CLIO: Santa Barbara, CA, USA, 1998.

110. Yemen Accuses Saudi Arabia of Over Seventy Border Violations. Available online: https://www.bbc.com/news/world-middleeast-37723472 (accessed on 20 October 2020).

111. Jehl, D. Border Clash Heightens Yemen-Saudi Tensions. Available online: https://www.nytimes.com/1998/07/26/world/ border-clash-heightens-yemen-saudi-tensions.html (accessed on 25 October 2020).

112. Okruhlik, G.; Conge, P.J. The politics of border disputes: On the Arabian Peninsula. Int. J. 1999, 54, 230-248. [CrossRef]

113. Yemen, Saudi Arabia Sign Border Deal. Available online: http://news.bbc.co.uk/2/hi/middle_east/788153.stm (accessed on 20 October 2020).

114. New Front in War on Terror. Available online: http://news.bbc.co.uk/2/hi/middle_east/2407597.stm (accessed on 20 October 2020).

115. U.S. Defends Yemen Strike. Available online: http://news.bbc.co.uk/2/hi/americas/2439305.stm (accessed on 23 October 2020).

116. Mitreski, A. Civil War in Yemen: A Complex Conflict with Multiple Futures; Arab Center for Research and Policy Studies: Doha, Qatar, 2015.

117. Popp, R. War in Yemen: Revolution and Saudi Intervention; No. 175; Center for Security Studies: Zurich, Switzerland, 2015.

118. Sharp, J.M. Yemen: Civil War and Regional Intervention; R43960; Congressional Research Service: Washington, DC, USA, 2015.

119. Lecoq, M. Some considerations on the current desert locust situation in East Africa. Metaleptea 2020, 40, $25-26$.

120. Meynard, C.N.; Lecoq, M.; Chapuis, M.P.; Piou, C. On the relative role of climate change and management in the current desert locust outbrteak in East Africa. Glob. Chang. Biol. 2020, 26, 3753-3755. [CrossRef] [PubMed]

121. FAO (Food and Agriculture Organization of the United Nations). Desert Locust Bulletin; No. 483; FAO: Rome, Italy, 2019; Available online: http:/ /www.Fao.org/ag/locusts/en/archives/archive/1366/2003/index/html (accessed on 23 October 2020).

122. FAO (Food and Agriculture Organization of the United Nations). Desert Locust Bulletin; No. 484; FAO: Rome, Italy, 2019; Available online: http:/ /www.Fao.org/ag/locusts/en/archives/archive/1366/2003/index/html (accessed on 23 October 2020).

123. FAO (Food and Agriculture Organization of the United Nations). Desert Locust Bulletin; No. 485; FAO: Rome, Italy, 2019; Available online: http:/ / www.Fao.org/ag/locusts/en/archives/archive/1366/2003/index/html (accessed on 23 October 2020).

124. FAO (Food and Agriculture Organization of the United Nations). Desert Locust Bulletin; No. 486; FAO: Rome, Italy, 2019; Available online: http:/ /www.Fao.org/ag/locusts/en/archives/archive/1366/2003/index/html (accessed on 23 October 2020). 
125. FAO (Food and Agriculture Organization of the United Nations). Desert Locust Bulletin; No. 487; FAO: Rome, Italy, 2019; Available online: http:/ / www.Fao.org/ag/locusts/en/archives/archive/1366/2003/index/html (accessed on 23 October 2020).

126. FAO (Food and Agriculture Organization of the United Nations). Desert Locust Bulletin; No. 488; FAO: Rome, Italy, 2019; Available online: http:/ / www.Fao.org/ag/locusts/en/archives/archive/1366/2003/index/html (accessed on 23 October 2020).

127. FAO (Food and Agriculture Organization of the United Nations). Desert Locust Bulletin; No. 489; FAO: Rome, Italy, 2019; Available online: http:/ / www.Fao.org/ag/locusts/en/archives/archive/1366/2003/index/html (accessed on 23 October 2020).

128. FAO (Food and Agriculture Organization of the United Nations). Desert Locust Bulletin; No. 490; FAO: Rome, Italy, 2019; Available online: http:/ /www.Fao.org/ag/locusts/en/archives/archive/1366/2003/index/html (accessed on 23 October 2020).

129. FAO (Food and Agriculture Organization of the United Nations). Desert Locust Bulletin; No. 491; FAO: Rome, Italy, 2019; Available online: http:/ /www.Fao.org/ag/locusts/en/archives/archive/1366/2003/index/html (accessed on 23 October 2020).

130. FAO (Food and Agriculture Organization of the United Nations). Desert Locust Bulletin; No. 492; FAO: Rome, Italy, 2019; Available online: http:/ /www.Fao.org/ag/locusts/en/archives/archive/1366/2003/index/html (accessed on 23 October 2020).

131. FAO (Food and Agriculture Organization of the United Nations). Desert Locust Bulletin; No. 493; FAO: Rome, Italy, 2019; Available online: http:/ / www.Fao.org/ag/locusts/en/archives/archive/1366/2003/index/html (accessed on 23 October 2020).

132. FAO (Food and Agriculture Organization of the United Nations). Desert Locust Bulletin; No. 494; FAO: Rome, Italy, 2019; Available online: http:/ /www.Fao.org/ag/locusts/en/archives/archive/1366/2003/index/html (accessed on 23 October 2020).

133. FAO (Food and Agriculture Organization of the United Nations). Desert Locust Bulletin; No. 495; FAO: Rome, Italy, 2020; Available online: http:/ / www.Fao.org/ag/locusts/en/archives/archive/1366/2003/index/html (accessed on 23 October 2020).

134. FAO (Food and Agriculture Organization of the United Nations). Desert Locust Bulletin; No. 496; FAO: Rome, Italy, 2020; Available online: http:/ /www.Fao.org/ag/locusts/en/archives/archive/1366/2003/index/html (accessed on 23 October 2020).

135. FAO (Food and Agriculture Organization of the United Nations). Desert Locust Bulletin; No. 497; FAO: Rome, Italy, 2020; Available online: http:/ /www.Fao.org/ag/locusts/en/archives/archive/1366/2003/index/html (accessed on 23 October 2020).

136. FAO (Food and Agriculture Organization of the United Nations). Desert Locust Bulletin; No. 498; FAO: Rome, Italy, 2020; Available online: http:/ / www.Fao.org/ag/locusts/en/archives/archive/1366/2003/index/html (accessed on 23 October 2020).

137. FAO (Food and Agriculture Organization of the United Nations). Desert Locust Bulletin; No. 499; FAO: Rome, Italy, 2020; Available online: http:/ /www.Fao.org/ag/locusts/en/archives/archive/1366/2003/index/html (accessed on 23 October 2020).

138. FAO (Food and Agriculture Organization of the United Nations). Desert Locust Bulletin; No. 500; FAO: Rome, Italy, 2020; Available online: http:/ / www.Fao.org/ag/locusts/en/archives/archive/1366/2003/index/html (accessed on 23 October 2020).

139. CLCPANO (Commission de Lutte Contre le Criquet Pelerin en Afrique du Nord-Ouest). Report of the 16th session of the Commission de Lutte Contre le Criquet Pelerin en Afrique du Nord-Ouest (CLCPANO); CLCPANA: Algiers, Algeria, 1991; Available online: http://www.fao.org/ag/locusts/fr/publicat/meeting/topic/regc/clcpano/1734/documents_1767.html (accessed on 20 October 2020).

140. FAO (Food and Agriculture Organization of the United Nations). Programme EMPRES en Region. Occidentale; FAO: Rome, Italy, 2016; Available online: http:/ / www.clcpro-empres.org (accessed on 5 November 2020).

141. FAO (Food and Agriculture Organization of the United Nations). Evaluation Final de la Phase II (2014-2017) du Programme EMPRES/Composante Criquet Pèlerin en Région Occidentale (EMPRES-RO); FAO: Rome, Italy, 2018; Available online: http:/ / www. fao.org/3/ca4005fr/ca4005fr.pdf (accessed on 5 November 2020).

142. Martini, P.; Lecoq, M.; Soumare, L.; Chara, B. Proposition de Programme de Lutte Contre le Criquet Pèlerin dans la Partie Occidentale de Son Aire d'habitat. Système de Prévention et de Réaction Rapide (EMPRES). Composante Acridienne (Criquet Pèlerin) en Région Occidentale; Food and Agriculture Organization of the United Nations: Rome, Italy, 1998; Available online: http:/ /www.fao.org/ ag/locusts / oldsite/PDF/meetings/EMPRESwest98f.pdf (accessed on 20 October 2020).

143. FAO (Food and Agriculture Organization of the United Nations). Desert Locust Watch; Archives 2005. Available online: http:/ / www.fao.org/ag/locusts/en/archives/archive/1366/2003/index.html (accessed on 23 October 2020). 